\title{
'As Hunters Find their Game by the Trace': Reading to Discover in The Anatomy of Melancholy
}

\author{
Angus Gowland, University College London
}

\begin{abstract}
The critical edition of Robert Burton's Anatomy of Melancholy, published by the Clarendon Press between 1989 and 2000, provided an invaluable resource for Burton scholars in the form of a generally reliable reading text and extensive critical apparatus, including three volumes of commentary devoted to tracing Burton's sources, identifying historical persons, events and geographical locations mentioned in the text, and explicating obscure allusions and technical terminology. Since its publication, however, there has been little attention paid to the contents of the Clarendon commentary, which contains many lacunae and entries that invite alteration. This is particularly regrettable, because Burton aimed the Anatomy partly at scholarly readers who were expected to read his cento in a similar way to a modern literary commentator, primarily by identifying its sources and allusions, and interpreting their deployment and manipulation in the text. This article seeks to supplement the Clarendon commentary by extending and revising its treatment of bibliographical sources, persons, geographical locations, and textual explanation. In doing so, it exemplifies a mode of reading that Burton expected for his book. It concludes by considering the implications for our understanding of the intended readership of the Anatomy.
\end{abstract}

The Clarendon edition of the text of Robert Burton's Anatomy of Melancholy has now been available for twenty-five years, and the volumes of accompanying commentary for nineteen. ${ }^{1}$ The prior publishing history of the Anatomy was not a happy one. Notwithstanding Burton's assiduous efforts to correct the proofs, ${ }^{2}$ he repeatedly lamented the errors that disfigured the

\footnotetext{
${ }^{1}$ Robert Burton, The Anatomy of Melancholy, ed. Rhonda Blair, Thomas Faulkner, and Nicolas Kiessling, and comment. J. B. Bamborough and Martin Dodsworth, 6 vols (Oxford, 1989-2000). References to this edition are given in the form 'Partition. Section. Member. Subsection; volume, page', excepting those to 'Democritus Junior to the Reader' (abbreviated as 'DJR') and the 1621 'Conclusion of the Author to the Reader' ('CR'); references to the commentary and textual notes give just the volume and page numbers. I have silently emended the orthography of the quotations from early printed versions of the Anatomy and other works throughout, so that 'i' is given as 'j', and 'u' as ' $v$ ' (and vice versa), ' $x$ ' as 'ae', and 'œe' as 'oe', as appropriate. Unless otherwise stated, all translations are my own.

${ }^{2}$ See the remarks of the publisher Henry Cripps in Burton, The Anatomy of Melancholy (Oxford, 1651), sig. A a a a a 4r. Some proof-sheets of earlier editions (mostly the fourth) showing many corrections in Burton's hand, survive today, having been used as waste paper in the bindings of other Oxford books; these are catalogued in J. K. Moore, Primary Materials Relating to Copy and Print in English Books of the Sixteenth and Seventeenth Centuries (Oxford, 1992), 73, 76-7, 79-80.
} 
editions published in his lifetime (DJR; I, 16-20, and CR; III, 471-2), ${ }^{3}$ and many of these persisted in the versions published from the later seventeenth to the later twentieth century. Taking the relatively reliable fourth edition (1632) as their copy-text, however, the Clarendon editors presented a meticulously cleaned-up Anatomy, one that was purged of obvious compositorial errors, included material that had been added by Burton to the fifth and sixth editions, and was appended with textual notes recording the extensive list of substantive variants between the different versions published between 1621 and 1651. In the three volumes of commentary, John Bamborough and Martin Dodsworth offered translations of most of Burton's Latin, and substantially extended the tradition of scholarly detective work dedicated to tracking down the sources of the thirteen thousand or so quotations and paraphrases of other works found in the text, and to providing explications of the many obscure ideas and allusions found throughout the book. However, whilst this excellent critical edition has become the version now used in all serious scholarship on Burton, it has also become unusual when compared with subsequent contributions to the field. In fact, the Clarendon edition seems to have brought the textual and bibliographical scholarship that it exemplifies to a grinding halt. One can hardly lament a proliferation of interesting interpretative studies, but it is peculiar that the Clarendon commentary, which as Bamborough acknowledged left the labour of tracing Burton's quotations to their sources far from complete (IV, x), has attracted only minor revision and little critical attention since its publication. ${ }^{4}$

That this kind of research has fallen into desuetude is regrettable, not only because it has been useful for scholarship on Burton's book, but also because it is related to a type of learned reading which the author expected his work to receive. The Anatomy was designed to be accessible to a range of readers, but even the most cursory glance through its pages, packed with classical allusions, quotations, bibliographical references, and untranslated Latin passages and notes, suggests that Burton wrote with more than half an eye on his scholarly friends and colleagues, at least some of whom could be counted on to scrutinise and evaluate these features of his work closely and critically. Indeed, such expectations are made explicit in the text of the Anatomy. In the preface of the first edition, Burton takes pains to guide his readers towards an appreciation of the 'composition and method' of his cento, which 'shewes a scholler', and is paradoxically labelled 'Omne meum, nihil meum, ... all mine and none mine' - a phrase attributed to Macrobius but, as his more erudite readers would surely have recognised, actually taken from the celebrated Renaissance cento, the Politica (1589) of Justus Lipsius. ${ }^{5}$ He also threatens

\footnotetext{
3 The multiple errors in the fifth edition, which was partially printed in Edinburgh before being completed in London and Oxford, are the subject of further complaint in Burton, The Anatomy of Melancholy (Oxford, 1638), sig. A a a a $4 \mathrm{r}$.

4 The honourable exception to the trend here is Christopher Tilmouth, 'Burton's St. Bernard', Notes and Queries, 47 (2000), 17679, which corrects Bamborough's commentary on the quotation of Bernard's Sermones at 1. 2. 3. 3; I, 255.

${ }^{5}$ Justus Lipsius, Politica: Six Books of Politics or Political Instruction, ed. and trans. Jan Waszink (Assen, 2004), 232; the quotation, whose significance is underlined by its appearance on the title-page of the 1621 and 1624 editions, is traced in the Clarendon commentary at IV, 26. See Kathryn Murphy, 'A Disagreeing Likeness: Michel de Montaigne, Robert Burton, and the Problem of Idiosyncrasy', in Montaigne in Transit: Essays in Honour of Ian Maclean, eds Neil Kenny and Richard Scholar (London, 2016), 225; Angus Gowland, The Worlds of Renaissance Melancholy: Robert Burton in Context (Cambridge, 2006), 22-5.
} 
anyone who might quibble with his quotational method, or with other perceived defects of 'art, invention, judgement, witte', or 'learning', with the promise that he will return their censure with interest. ${ }^{6}$ The message is driven home in the 'Conclusion of the Author to the Reader'. “[W]e are both schollers', he writes here, and asks for 'a friendly admonition' for a host of stylistic and scholarly faults: passages that are 'too Satyricall \& bitter' or 'too Comicall, broad, or lightly spoken', 'harsh compositions, Tautologicall repetitions, perturbations of tences and numbers \&c.', amateurish 'matter it selfe or method', typographical errors, loose and selective translations, quotations taken from translated versions rather than 'the Originall', and the ordering of names 'not according to Chronologie'. Any reader who responds with 'bitter invective', however - and two references to Scaliger's famously devastating critique of Cardano's De subtilitate express the worry - is warned with a threat of wrangling that will only 'trouble and wronge our selves' and 'make sport for others' (III, 469-73).

After the initial publication of the Anatomy, Burton evidently felt the need to provide more guidance to his readers, re-emphasising the book's scholarly credentials and further strengthening his defences. In the 1624 edition, the 'Conclusion' was removed and much of its content relocated to the preface (DJR; I, 11-19), where the self-justification could do its work pre-emptively before the main text. ${ }^{7}$ In 1628 , nevertheless, the preface records the author's complaint that although he has been 'honoured by some worthy men', he has also been 'vilified by others' who have 'scornfully rejected' his book(I, 14-15). In 1632, the prefatory Latin poem 'Democritus Junior ad librum suum' sums up Burton's expectations, preparing the book for its potentially profitable encounter with a variety of people, and instructing it to beg mercy from its academic readers for any blunders, but also warning off unsuitable readers: the 'severe Cato' (morosus Cato) and 'harsh Senator' (tetricus Senator), who lack the leisure for a proper engagement with the work; the 'absurd Rhetorician' (Rhetor ineptus) and the 'critical reader' (Criticus Lector), quibblers to whom the book should 'snarl, growl, and refuse to open up'; and worst of all, the 'barbarous, rude and ignorant critic' (Barbarus, indoctusque rudis spectator), who should be chased off with a club. Instead, the Anatomy welcomes the 'wise, affable, and obliging reader' (cordatus facilis lectorque benignus), who approaches the work with prudence and generosity, and is the benign counterpart of the lector male feriatus (I, lxvi-lxviii; cf. DJR; I, 114). This kind of reader, who would turn leisure into beneficial business in the same manner as the author (otium in utile verterem negotium) (I, 7), in this respect meets the author's expectation that 'the reader will be like me' (par mihi lector erit) (I, lxvi).

Burton also came to realise, it seems, that his readers would be more likely to be benevolent and generous if they were directed more explicitly towards an appreciation of the creative aspects of his cento. The discussion of his method and style, a portion of the preface

\footnotetext{
${ }^{6}$ Burton, Anatomy (1621), p. 9. See also the Latin address 'Lectori male feriato' (DJR; I, 114).

${ }^{7}$ Here I differ from the Clarendon editors, who suggest that the reason for the suppression of the 1621 'Conclusion' is the subsequent expansion of the last Subsection on the 'Cure of Despaire' (III, 466).
} 
which significantly expanded in the second and third editions (DJR; I, 8-20), ${ }^{8}$ thereby came to incorporate not only new material in defence of his borrowings, but also the suggestion that the reader should be alert to the possibility, as he says, that 'I may likely adde, alter, and see farther than my Predecessors' [I, 11-12]. The assistance becomes more explicit in the 1628 copy, which re-emphasises the propriety of Burton's scholarly acknowledgements in a longer description of how 'I cite \& quote mine Authors', and employs the Erasmian metaphor of the body's natural digestion of foodstuffs to point to the manner in which he has creatively 'dispose[d]' his borrowed materials. He also reasserts his ownership of the work by drawing the attention of his Latinate readers to the fact that the quotational method of the cento involves the redeployment of old words for new purposes: 'apparet unde sumptum sit (which Seneca approves) aliud tamen quam unde sumptum sit apparet' ('it's clear where it's taken from ... but it appears as something different from the original') [I, 11]. For those who had read Lipsius's Politica these were familiar instructions. As Lipsius observes in his introductory account of the form and purpose of his work, a good cento is especially demanding of its readers, to whom he issues a series of 'admonitions, or warnings': that they must read the book more than once, carefully observe the distinction between the words of the author and those of his sources, and pay close attention to punctuation and annotation. Perhaps the most useful piece of advice for later readers of the Anatomy, though, is given in Lipsius's explanation of 'the rules and habits of the Cento'. Here, seeking to disarm any critics of the looseness of his quotations, he reminds them that since antiquity it has been essential to this form of writing that 'departures from the original meaning are always allowed and even praised'. ${ }^{9}$

To write a cento, then, was in part to issue an invitation to a community of learned readers to put their humanist education into practice. Such readers were expected to exercise their memory and literary discernment, and to appreciate the skilful deployment of quotations with bibliographical references, particularly by identifying changes of meaning generated by their transposition from old to new settings; and then, as they had been trained, to set such manoeuvres within an expansive web of literary references and intertextual allusions, using their ingenuity to supply the subtle and potentially multiple meanings that could arise from the appropriation of sources previously quoted or paraphrased by other authors. ${ }^{10}$ In fact Burton's cento offered more to those who were able and willing to go further, also presenting a plethora of unattributed quotations and allusions, which if they could be recognised or traced to their origins would potentially unlock other layers of textual significance - whilst providing, one

\footnotetext{
${ }^{8}$ In the first edition, this section (running from 'Yea but you will inferre, ...' to 'The last and greatest exception is ...'), was just over three quarto pages in length: Anatomy (1621), pp. 7-10; in the second, now incorporating some of the 1621 'Conclusion', it is just under six folio pages: Anatomy (1624), pp. 5-11; in the third, it is just over eight folio pages: Anatomy (1628), pp. 6-14. Subsequent editions have only minor changes in this part.

${ }^{9}$ Lipsius, Politica, 236-7.

10 Hugo Tucker, 'From Rags to Riches: The Early Modern Cento Form', Humanistica Lovaniensia, 62 (2013), 3-67, at 14, and 'Justus Lipsius and the Cento Form', in (Un)masking the Realities of Power: Fustus Lipsius and the Dynamics of Political Writing in Early Modern Europe, eds E. De Bom, M. Janssens, J. Papy, and T. Van Houdt (Leiden and Boston, 2010), 163-92, at 190-2; Ann Moss, 'The Politica of Justus Lipsius and the Commonplace-Book', Fournal of the History of Ideas, 59 (1998), 421-36, at 4289, and more generally, Renaissance Truth and the Latin Language Turn (Oxford, 2003), 251.
} 
presumes, bursts of pleasure from successful discoveries. Such expectations and inducements were closely related to others in the Anatomy, perhaps most importantly those generated by its wealth of historical, mythological, literary, geographical, and philosophical knowledge. Much of this, in notable contrast to the medical doctrine, appears on the page without explanation or detailed comment, inviting its readers to deploy their own learning whilst appreciating that of the author. ${ }^{11}$ Burton also assumed, as is indicated by his repeated self-justifications and attacks on malevolent pedants, that his text would be subjected to close linguistic and stylistic analysis, with readers not only checking his quotations against the originals, but scrutinising his grammar and choice of words, his rhetorical tropes and figures, his bibliographical sources, and even his punctuation and typography.

Nearly four hundred years later, it is striking how closely the labours of the Clarendon commentary on the Anatomy, in which the identification and discussion of quotations and allusions is interleaved with the explication of the more or less obscure content of Burton's text, align with the activities expected of its seventeenth-century scholarly readers. This is partly an index of the lasting impact upon literary studies in the West of humanistic textual and bibliographical techniques, but it is also due to the specific ancestry of the genre of the scholarly commentary, in which the traditional labour of literal exposition was enriched by humanists with the philological analysis of vocabulary, and the discussion of sources and references. Unsurprisingly, Burton was very familiar with this kind of commentary. ${ }^{12}$ In revising and supplementing the Clarendon commentary on the Anatomy in this article, my main purpose is therefore not only to recommence a particular form of scholarship, but to re-engage in a kind of historicised reading which the author expected his text to receive. I attempt to respond to Burton's instructions about how best to read his cento, not only following the path from his quotations to their sources, but also noting where he has evidently followed through on his promise to 'adde, alter, and see farther' than them by incorporating his own inflections of meaning. This, it seems to me, is at least partly what Burton had in mind when describing the way in which his readers would be able to discover the authorial 'Genius' in the text, as he put it in another borrowing from Lipsius, 'as Hunters find their game by the trace' (I, 13; cf. CR, III, 469). ${ }^{13}$

In what follows, I revisit Burton's work by implementing the kind of analysis outlined above, but from a succession of different angles. These provide four occasionally overlapping categories for the discussion, within each of which I propose a set of revisions and supplements

\footnotetext{
${ }^{11}$ On the encyclopedic erudition of the Anatomy, see E. Patricia Vicari, The View from Minerva's Tower: Learning and Imagination in 'The Anatomy of Melancholy' (Toronto, 1989) and Kathryn Murphy, 'Robert Burton and the Problems of Polymathy', Renaissance Studies, 28 (2014), 279-97.

12 On the humanistic commentary as a genre see Jill Kraye, 'Renaissance Commentaries on the Nicomachean Ethics', in The Vocabulary of Teaching and Research between Middle Ages and Renaissance, ed. O. Weijers (Turnhout, 1995), 96-117. Burton cites many humanistic commentaries throughout the Anatomy, including works by Paolo Beni, Filippo Beroaldo, Giles de Maizières (Maserius), Jacob Mayer, Philipp Melanchthon, Claude Mignault, Giovanni Pico della Mirandola, Enea Silvio de' Piccolomini (Pius II), Johann Sleidan, André Tiraqueau, Livinus van der Beken (Torrentius), Giovanni Piero dalle Fosse (Valerianus), and Raffaele Maffei (Volateran): in the Clarendon biobibliography, see VI, 315, 383, 384, 386, 400, 420, 428, and 430.

13 The source of the hunting metaphor is traced by Bamborough and Dodsworth to Lipsius's Epistolae miscellaneae 1.45 (IV, 30 ).
} 
to the Clarendon commentary: (I) bibliographical sources; (II) persons; (III) geographical locations and place names; and (IV) explanatory commentary necessary or at least helpful for understanding the literal sense and broader significance of the text. I conclude (section V) with some remarks on the implications for our understanding of the text of the Anatomy and its intended readership. Before proceeding, however, it must be acknowledged that the discoveries and suggestions presented here have been assisted by the availability of electronic texts and digital tools. That the Clarendon commentators achieved as much as they did without the array of resources now at our disposal serves to underline their diligence and ingenuity. It is worth remembering that although Burton disliked pedantic quibbling, he welcomed critical attention intended to assist and improve: 'Nam si culparit, quaedam culpasse juvabit, / Culpando faciet me meliora sequi' [I, lxviii].

\section{Bibliographical sources.}

The Anatomy presents those who seek to trace the sources of its quotations with many challenges. Burton gives many references in the text, but these are often vague or misleading; apparent quotations in italics are often imprecise or actually paraphrases, are sometimes unattributed, and in some cases are not quotations at all but repetitions or glosses of points already made; excerpts from multiple places are often presented in the text without distinction; and they are often taken from intermediary sources, sometimes repeating oddities and errors of transmission. ${ }^{14}$ Bearing these difficulties in mind, in this section I fill some of the bibliographical lacunae in the Clarendon commentary, and also revise some of its more speculative musings. As we shall see, this process involves encountering areas of the text that are less helpful than first they seem, and where understanding the playful quotational language of the Anatomy now requires some labour.

Burton's habit of mining neoteric works for quotations from ancient authors without indicating his immediate debt, which was widespread in humanistic literary and scholarly circles, certainly complicates the task of the commentator. One such instance occurs towards the end of the satirical preface, where in the third edition Burton amplifies his vituperation against 'negligent servants' (DJR; I, 99) with a description of them as 'servi furaces, Versipelles, cal[l]idi, occlusa sibi mille clavibus reserant, furtimq[ue] raptant, consumunt, liguriunt', with a marginal note attributing the passage to 'Plautus Aulular'. ${ }^{15}$ As Bamborough and Dodsworth observe (IV, 150-1), this is found neither in the anonymous late comedy Querolus sive Aulularia often attributed to Plautus, nor in any of the genuine works of Plautus; they speculate that Burton may have been thinking of the slave Strobilus (in Plautus) or Pantomalus (in Querolus). The quotation is

\footnotetext{
${ }^{14}$ See the discussion by Bamborough in the Clarendon commentary at IV, x-xiii.

${ }^{15}$ Burton, The Anatomy of Melancholy (Oxford, 1628), 68. The comma between 'Versipelles' and 'callidi', which is missing in the 1632 and 1638 editions, but is present in the 1651 copy as well as in Urcéo’s original and Agrippa's quotation, should be retained. Two of the Cambridge University Library copies of the third edition (Hunter b.62.2 and Syn.4.62.19) suggest that the error arose from poor typesetting of that edition.
} 
actually from the new fifth act for the Aulularia written by the Italian humanist Antonio Urcèo (1446-1500), professor of Greek at Bologna. ${ }^{16}$ Urcèo's supplement, which was apparently in circulation in the early 1480s, was well-regarded and often included in sixteenth-century editions of the comedies. ${ }^{17}$ It was not, however, included in the edition of Denis Lambin, which Burton owned in the version published by Jacques Stoer at Geneva in 1610, and which he appears to have used elsewhere in the Anatomy. ${ }^{18}$ Possibly he took the passage from a different edition of Plautus, but a more likely intermediary source is the De incertitudine et vanitate scientiarum et artium of Henrich Cornelius Agrippa, to which Burton refers seven times elsewhere in his preface (DJR; I, 9, 40, 48, 52, 100, 104), and which also deploys Urcèo's lines - misleadingly introduced with the assertion that 'de iis ita loquitur Strophilus servus apud Plautum in Aulularia' - in a satirical discussion of slaves. ${ }^{19}$

A similar difficulty is presented by one of the anecdotes added by Burton in the fourth edition to illustrate the power of beauty in his discussion of love melancholy: 'A fly lighted on Malthius cheeke as he lay a sleep, but why? Not to hurt him, as a parasite of his standing by well perceaved, non ut pungeret sed ut oscularetur, but certainly to kisse him, as ravished with his divine lookes' (3. 2. 2. 2; III, 71-2). ${ }^{20}$ An accompanying note refers to 'Atheneus lib. 8', which as Bamborough notes must be a mistake, since book 8 of the Deipnosophistae is about fish. Instead, he suggests we turn to the story of the flatterer Nicesias at 6. 249, who fawned over Alexander the Great by pointing out how the flies that had bitten the emperor were especially privileged for having tasted his blood (VI, 55). But this leaves several problems: the obvious differences in the details of the two stories; the Latin quotation, which does not correspond to any phrases in the Greek of Athenaeus, and is not found in the translation by Jacques Daléchamps occasionally used in the Anatomy; ${ }^{21}$ and also the specific appearance in Burton's text of 'Malthius', whom Bamborough speculates may be the first-century BC Arabian king Malchus the Nabataean, but who is not mentioned anywhere by Athenaeus. I suggest that Burton is not using Athenaeus, but an intermediary source, the De eloquentia sacra et humana (1619) by the Jesuit Nicolas Caussin. Amongst the epideictic exercises presented by Caussin in the De eloquentia is one depicting the 'Adulator', said to be 'based upon Athenaeus book 6 and the observations of other historians' ('Expressus ex Athenaeo, lib. 6. \& aliis historicorum sensibus'), and embellished freely in his own style ('nostro vero stylo donatus'). Caussin's description begins with an immoral rich man, called either 'Malthinus' or 'Malthinas', in the habit of calling

\footnotetext{
16 Carlo Malagola, Della vita e delle opera di Antonio Urceo detto Codro (Bologna, 1878), 384-409.

17 See, for example, Aulularia Plautina, comoediarum lepidissima, quae etsi alias incompleta, a Codro Urceo tamen est perfecta, cum familiari explanatione (Strassburg, 1520); the quotation is at f. $43 \mathrm{v}$.

18 Plautus, Comoediae viginti. Variae lectiones ac notae, ed. Denys Lambin (Geneva, 1610); the incomplete Act V is at pp. $124-25$ in this copy (Christ Church f.10.6; Nicolas K. Kiessling, The Library of Robert Burton [Oxford: Oxford Bibliographical Society, 1988], no. 1254). Kiessling's catalogue should now be supplemented with the discussion of Burton's books in Ralph Hanna and David Rundle, A Descriptive Catalogue of the Western Manuscripts to c. 1600, in Christ Church, Oxford (Oxford, 2017).

19 Heinrich Cornelius Agrippa, De incertitudine \& Vanitate Scientiarum \& Artium, atque excellentia verbi Dei declamatio (Paris, 1531 ), ff. $97 \mathrm{r}-\mathrm{v}$.

20 Burton, Anatomy (1632), 462.

21 See Athenaeus, Deipnosophistarum libri quindecim, tr. Jacques Daléchamps (Lyon, 1583), VI, 187.
} 
Alexander by the name of Jove. ${ }^{22}$ It includes the tale of the fly, relating Malthinus' fawning words 'cervicem illam roseam appetiise, quis non appeteret? involasse, non ut pungeret, sed ut oscularetur'. ${ }^{23}$ The Anatomy has replaced 'Malthinus' with 'Malthius' (probably because the compositor missed a contraction in Burton's manuscript), switched his role in the story, and changed book 6 of Athenaeus into book 8; but it still seems likely that the De eloquentia sacra et humana, which is used earlier in the third Partition (3. 1. 1. 1; III, 1; 3. 1. 1. 2; III, 9, 16) is the immediate source of the anecdote and quotation here. Elsewhere in the Anatomy, the clues are more helpful in tracking Burton's use of intermediary sources for classical quotations. The speech of Periplectomenus on the ease of a childless life excerpted from the Miles gloriosus of Plautus, for instance, is introduced with a description of the character as 'that good personat old man, delitium senis' (3. 2. 5. 3; III, 239). The latter phrase is not from Plautus, but from the discussion of Periplectomenus in the Observationum historico-politicarum decades (1621) by the German scholar Michael Piccart. Given that Piccart goes on to quote the same lines of Plautus, it seems likely that Burton, who added this passage in his fifth edition, copied them from this source. ${ }^{24}$

Only the most fanatically devoted readers, perhaps, would want to pursue many more investigations of this kind, but in some cases they do shed light upon puzzling passages in the Anatomy. This is particularly true of places where Burton quotes Hermetic philosophical materials, some of which have remained untraced or unsatisfactorily attributed. Indeed the very first poetic quotation in the first Partition, 'Ut diis consimiles parturiat deos', which is attributed in the text to 'an old Poet' (1. 1. 1. 1; I, 122) and left unidentified in the Clarendon commentary (IV, 171), is from the Crater Hermetis by the philosopher-poet Ludovico Lazzarelli (1447-1500). ${ }^{25}$ The poem was available in the Hermetica collected by Jacques Lefèvre d'Étaples, published in Paris in 1505 and 1522, which also included Ficino's Latin translation of the Pimander and the Asclepius along with Lefèvre's commentaries. ${ }^{26}$ Burton did not possess a copy of this book, however, and according to Thomas James's catalogue of 1620, neither did the Bodleian. It seems likely that it was again from Agrippa that he obtained the verse, this time from the $D e$ occulta philosophia libri III, a work used frequently in the Anatomy that quotes 'Lazzarellus in Cratere Hermetis' towards the end of chapter 36 in book 3 (in the 1567 edition owned by

\footnotetext{
22 Nicolas Caussin, Eloquentiae sacrae et humanae parallela libri XVI (Paris, 1619), 453a. The name 'Malthinus'/'Malthinas' may allude to the foppish character in Horace, Satires I. 2. 25-6.

${ }^{23}$ Caussin, Eloquentiae sacrae, 453b.

${ }^{24}$ Michael Piccart, Observationum historico-politicarum decades, 3 vols (Nürnberg, 1621), III, 306. Both Piccart and Burton give 'interpartiant' at the end of the third line of the quotation, whereas the Lambin edition of Plautus, which Burton owned, prefers 'inter eos partiam' and gives 'interpartiant' as a variant reading in the margin: Plautus, Comoediae viginti, p. 443.

25 On this work see S. Sosti, 'Il "Crater Hermetis" di Ludovico Lazzarelli', Quaderni dell'Istituto Nazionale di Studi sul Rinascimento meridionale, 1 (1984), 101-32. For a modern translation see Wouter J. Hanegraaf and Ruud M. Bouthoorn, Lodovico Lazzarelli (1447-1500): The Hermetic Writings and Related Documents (Tempe, AZ, 2005), 165-269 (the line quoted in the Anatomy is at 27.1, 1. 63 , p. 254).

${ }^{26}$ Jacques Lefèvre d'Étaples (ed.), Pimander. Mercurij Trismegisti liber De sapientia et potestate dei. Asclepius. Eiusdem Mercurij liber De voluntate diuina. Item Crater Hermetis a Lazarelo Septempedano (Paris, 1505); Pimander. Mercurij Trismegisti liber De sapientia et potestate dei. Asclepius. Eiusdem Mercurij liber De voluntate diuina. Item Crater Hermetis a Lazarelo Septempedano (Paris, 1522).
} 
Burton, the passage is at p. 412). ${ }^{27}$ The same process is at work behind Burton's references to Hermes Trismegistus and excerpts from the Hermetica in the Anatomy. ${ }^{28}$ In the preface, he remarks ironically that '[a] man is a miracle of himselfe, but Trismegistus addes, Maximum miraculum homo sapiens, a wise man is a wounder' (DJR; I, 64); Bamborough and Dodsworth gloss this passage with a quotation from Francisco Patrizi's translation of the Asclepius, included in the 1593 edition of his Magia philosophica. But Patrizi's version omits any mention of the wise man, and supplies the positive rather than the superlative adjective ('magnum miraculum, est homo'). ${ }^{29}$ In fact, Burton's quotation does not correspond to the text given in any Latin edition of the Asclepius. ${ }^{30}$ It does, however, bear a close resemblance to a passage in the Liber de quadruplici vita (1507) by the occult philosopher and physician Symphorien Champier. The first chapter of Champier's 'De vita sana' reports the view of Hermes that ' $[\mathrm{m}]$ agnum miraculum est homo, maximum miraculum est homo sapiens', and I suggest that this is the intermediary source of this remark in the Anatomy. ${ }^{31}$

Other quotations from the Hermetica show that Burton probably did not use the Patrizi translation at all. After listing the drawbacks of bachelorhood in the third Partition, he notes the duty of procreation and adds the injunction 'as Trismegistus to his sonne Tatius, have no commerce with a single man', to which he attaches the further instruction 'Noli societatem habere, $\mathcal{E}^{2} \mathrm{c}$.' in a marginal note (3. 2. 5. 5; III, 266). Bamborough's cross-reference to what he calls 'Aesculapius, bk. 9'32 as found in Patrizi's Magia philosophica, f. 157v (VI, 170) is unsatisfactory: leaving aside Burton's substitution of Hermes's son Tat ('Tatius') for Asclepius, Patrizi's translation of the relevant passage reads quite differently as 'Ergo o Asclepi, nemini qui filiis careat congratuleris' ('Therefore, Asclepius, you should congratulate no-one who is childless'). The text being loosely rendered in Burton's English is more likely to have come from the translation of Marsilio Ficino, which was available in Lefèvre's edition of the Hermetica as well

\footnotetext{
${ }^{27}$ Heinrich Cornelius Agrippa, De occulta philosophia libri tres (Paris, 1567); Christ Church f.6.18, Kiessling, The Library of Robert Burton, no. 14.

${ }^{28}$ Bamborough's commentary on 1. 3. 1. 3; I, 396, where the Anatomy refers to 'Ptolomeus in his centiloquie, Hermes, or whosoever else the author of that Tract', proposes Thaddaeus Haggecius, Astrologica opuscula antiqua (Prague, 1564) as a possible source (V, 45). The omission of Ptolemy in the entry is misleading, since Burton has in mind the disputed authorship of the pseudoPtolemaic Centiloquium, sometimes attributed to Ptolemy and sometimes to Hermes. The Centiloquium was in wide circulation, often appended to the Tetrabiblos (though not in the 1519 translation owned by Burton: Kiessling, Library of Robert Burton, no. 1300). See Moritz Steinschneider, Die hebraeischen Übersetzungen des mittelalters und die Fuden als Dolmetscher (Berlin, 1893), 514-15, $527-9$.

${ }^{29}$ Francesco Patrizi, Magia philosophica (Hamburg, 1593), f. 50r.

${ }^{30}$ In the influential version of Ficino, the phrase is given as 'magnum miraculum est homo' (Opera, vol. 2 [Basel, 1576], 1859); see also Lefèvre d'Étaples (ed.), Pimander (1505), 22; the translation of (pseudo-)Apuleius owned by Burton (Kiessling, Library of Robert Burton, no. 45), has 'Propter hoc o Asclepi, magnum miraculum est' (Apuleius, Opera, quae quidem extant, omnia, comment. Filippo Beroaldo and Gottschalk Stewech, vol. 3 (Basel, 1620), 398.

31 Symphorien Champier, Liber de quadruplici vita Theologia Asclepij hermetis trismegisti discipuli cum commentariis eiudem domini Simphoriani (Lyon, 1507), sig. b ijr.

32 This is misleading, since in Patrizi's work it is bk 9 of what is termed the 'Sermo universalis', or the 'Discourse of Hermes Trismegistus to Asclepius' (f. 152v), not the Asclepius; in modern editions, it is the Corpus Hermeticum II (Hermetica, ed. and tr. Brian Copenhaver [Cambridge, 1992], 8-14).
} 
as in Ficino's Opera, ${ }^{33}$ and fits Burton's prose more closely than Patrizi's version: 'Igitur o Asclepi, cum homine, qui nullos genuit filios, nullum habeto commercium' ('Therefore, Asclepius, have no commerce with a man who produces no children'). ${ }^{34}$ The notion that Burton used the Patrizi translation is effectively discredited by a passage added to the discussion of the symptoms of superstition in the second edition: 'O Aegypt (as Trismegistus exclaimes) thy religion is fables, and such as posterity will not beleeve', with an attached note giving the Latin text as 'O Aegypte, religionis tuae solae supersunt fabulae, eaeque incredibiles posteris tuis' (3. 4. 1. 3; III, 369). The Clarendon commentary supplies Asclepius 24 as the reference (VI, 239), but does not note that the Patrizi translation omits words ('incredibiles posteris tuis') that are included in Burton's text. ${ }^{35}$ It is far more likely that he was referring to Ficino's translation, which includes the passage in full, either in the Lefèvre edition or in Ficino's Opera, or that he was using his own edition of pseudo-Apuleius. ${ }^{36}$

An additional layer of complication is introduced by another apparent quotation of the Asclepius in a passage inserted in the 'Digression of Spirits' in the 1624 edition. Here Burton observes that 'the Gentiles gods were Divells (as Trismegistus confesseth in his Asclepius) and hee himselfe could make them come to their Images, by Magicke spells', and attaches a marginal note with the quotation 'Dii gentium Daemonia, $\mathcal{E}^{2}$. ego in eorum statuas pellexi' (1. 2. 1. 2; I, 185). The Clarendon commentary cross-refers to modern editions of the Asclepius (23-4 and 37-8) and the discussion of Egyptian idolatry in De civitate Dei VIII.23, but notes the problem that neither source states Hermes' ability to introduce the souls of angels or devils into their statues, and leaves the Latin quotation unattributed (IV, 222). Indeed, whilst Burton's note evidently paraphrases these places in the Asclepius and the De civitate Dei, none of its text is found in either. It does partially appear, however, in the Latin translation of De la verite de la religion Chrestienne by Philippe Duplessis-Mornay, which Burton owned and drew upon elsewhere in the Anatomy. ${ }^{37}$ In chapter 22, Duplessis-Mornay reproduces a passage, attributed in a marginal note to the translation of the Asclepius by (pseudo-)Apuleius, which begins with 'Homo igitur statuas ad similitudinem suam facit, in quas arte Magica spiritus invitat' and concludes with 'sed sub his nominibus

\footnotetext{
33 Lefèvre d'Étaples (ed.), Pimander (1505), f. 10r; Ficino, Opera, vol. 2, 1841.

34 The origin of Burton's injunction 'Noli societatem habere, \&̊c.' remains a mystery; I have found close variations only in unlikely sources, for example in the De constitutionibus apostolicis, B. Clemente Roman auctore, libri octo, tr. Giovanni Carlo Bovio (Venice, 1563), bk VI, ch. 4, f. 76v, and John Jewel, A defence of the Apologie of the Churche of Englande ... (London, 1567), 569.

35 In Patrizi's edition the passage reads 'O Aegypte, Aegypte religionum tuarum sola supererunt verba lapidibus incisa, tua pia facta narrantibus' (Patrizi (ed.), Pimander, f. 70r). The words are also missing in the version included in Franceso Patrizi, Nova de universis philosophia (Ferrara, 1593), 4.

${ }^{36}$ Lefèvre (ed.), Pimander, f. 27r; Ficino, Opera, vol. 2, 1865; Apuleius, Opera, vol. 3, 418, all of which however have 'suis' rather than 'tuis' in the second clause; see, similarly, Opera omnia quae exstant, ed. Bonaventura Vulcanius (Lyon \& Paris, 1601), 605; Opera omnia quae extant, ed. Gerhard Elmenhorst (Frankfurt, 1621), 90. Burton's use of 'tuis' in this quotation corresponds, probably fortuitously, with the standard Budé edition: A. D. Nock (ed.) and A.-J. Festugière (tr.), Corpus Hermeticum, 4 vols (Paris, 1945), 2. 327.

${ }_{37}$ Philippe Duplessis-Mornay, De veritate religionis Christianae liber; Adversus Atheos, Epicureos, Ethnicos, Iudaeos, Mahumedistas, छ caeteros Infideles (Herborn, 1592): Christ Church f.4.31(1); Kiessling, Library of Robert Burton, no. 1088. Other references to the work are listed in Dodsworth's biobibliography (VI, 389).
} 
coluntur daemones, quos ego in eorum statuas pellexi. ${ }^{38}$ These words do not come directly from the Asclepius; the passage is actually, as another marginal note on the page referring to Augustine suggests, a stitching-together by Duplessis-Mornay of an adapted quotation from the Asclepius in De civitate Dei VIII.23 and a paraphrase of VIII.26, which had been rendered in French in the 1581 edition of De la verité. In the latter work, he suggests that spirits are drawn into the statues by human agency ('L'homme donq fait des statues à sa semblance, esquelles il invite par art magique les esprits'), ${ }^{39}$ and this apparently became the basis for the Latin text in the $D e$ veritate. ${ }^{40}$ In any case, Burton was clearly using the De veritate, rather than the De civitate Dei or the Asclepius itself. The same work is also the likely source of another unattributed quotation in the account of 'excessive' religious melancholy in the third Partition, 'Si dii cur plangitis, si mortui cur adoratis?' (3. 4. 1. 3; III, 374), which was appended in 1628 to another excerpt from the Octavian of Minucius Felix but is left untraced in the Clarendon commentary (VI, 245). The saying, which originates in a fragment sometimes spuriously attributed to Heraclitus, is put in the mouth of Plato by Duplessis-Mornay in the same chapter of the De veritate. ${ }^{41}$

Elsewhere in the Anatomy it is hard to avoid a description of the text as blatantly misleading. One of the clearest cases, added in the fourth edition, is presented by the playful extended argument in utramque partem about marriage, which presents and then inverts arguments for the benefits of matrimony (3. 2. 5. 5; III, 266-68). Burton claims that these have been 'delivered in twelve motives, to mittigate the miseries of marriage, by Facobus de Voragine', and attaches a marginal note partially (mis-)quoting Genesis 2:18 in the Latin Vulgate: 'Adjutorium simile $\mathcal{E}^{2}$.' After finding nothing resembling these 'motives' in the works of the medieval Italian chronicler, Bamborough concludes that the reference is a 'mystery', and argues instead that this part of the Anatomy is a reworking of a passage in Erasmus's 1518 Encomium matrimonii (VI, 170; cf. IV, xi). This is an unsatisfactory attribution: Erasmus's work is not organised into numbered 'motives', and much of the vocabulary and content of Burton's quotation follows Erasmus only very loosely (indeed, 'motive' no. 8, 'Vinculum Conjugalis charitatis adamantinum' is missing completely). Burton was almost certainly not using the Encomium matrimonii, but a later work that was itself indebted to Erasmus, the Loci communes (1545) by the Lutheran theologian Urbanus Rhegius. In the chapter devoted to arguments 'De matrimonio', Rhegius begins a list of those 'A Jucundo' - not numbered, but separated by line-breaks in the 1562 Opera - with the (mis-)quotation 'Genesis 2. Adiutorium simile'; the next six arguments correspond to numbers 1-6 in the Anatomy with only minor variations of spelling, grammar, and

\footnotetext{
38 Philippe Duplessis-Mornay, De veritate religionis Christianae liber, ch. 22, 370.

39 Philippe Duplessis-Mornay, De la verité de la religion Chrestienne contre les athées, Epicuriens, Payens, Juifs, Mahumedistes et autres infideles (Antwerp, 1581), ch. 22, 510. The contemporary translation of Gentian Hervet is, unsurprisingly, more accurate on this point (Augustine, De la cité de Dieu, tr. Gentian Hervet, 2nd edn [Paris, 1579], VIII. 23, 247). Thanks to Brian Copenhaver for assistance in tracking this source.

40 Duplessis-Mornay's paraphrase also masquerades as a direct quotation from the Asclepius in James Mason, The anatomie of sorcerie (London, 1612), 57.

${ }^{41}$ Duplessis-Mornay, De veritate, 372; cf. Hartmut Erbse, Fragmente Griechischer Theosophien (Hamburg, 1941), fr. 127, 69. Burton refers to ch. 22 of the De veritate a few lines earlier, in a passage added in the second edition, at 3. 4. 1. 3; III, 374. See also the description of Protagoras's mockery of the 'old Egyptians' in Peter Heylyn, Theologia veterum (London, 1654), 17.
} 
punctuation. ${ }^{42}$ Burton has however switched the order of nos 7 and 8 in Rhegius's list; his no. 9 runs together the first and second arguments 'A Fructu' which follow those 'A Jucundo'; and nos 10, 11 and 12 are the third and last two arguments of Rhegius in the same category. In the absence of a source that fits even more closely to Burton's text, I suggest that he used Rhegius. $^{43}$

Similar confusion is created by Burton's remark, in the Subsection on the symptoms of 'excessive' religious melancholy, that the spectacle of contending superstitious is 'fit for Calphurnius \& Democritus to laugh at', to which is attached a marginal note: 'Pleno ridet Calphurnius ore. Hor.' (3. 4. 1. 3; III, 364). Bamborough speculates that the reference to Horace may refer either to the (genuinely Horatian) phrase 'de lana caprina' several clauses earlier in the same sentence, or perhaps to Ars poetica 94 ('iratusque Chremes tumido delitigat voce') (VI, 236). But it is unnecessary to infer the inaccuracy of the Anatomy here, as the saying appears in similarly controversial religious contexts in both the Apologie or defence of the watch-word (1610) by Sir Francis Hastings, ${ }^{44}$ and in the second edition of Foxe's Acts and Monuments (1570), where a near-identical marginal note ('Pleno ridet Calphurnius ore. Horat.') serves as a commentary on a 'ridiculous pageant' in 1541 that involved a monk from Gloucester College in Oxford, 'whereat Calphurnius mighte well laugh with an open mouth'. ${ }^{45}$ The origin of the saying remains obscure, however; Foxe's eccentric use of the character of (presumably) the bucolic poet Calpurnius, who also appears alongside Democritus as an allegedly satirical figure in Foxe's first edition (1563), remains perplexing. ${ }^{46}$ Nevertheless, the Acts and Monuments seems likely to be Burton's source here. ${ }^{47}$

A more subtle type of misleading occurs in Burton's discussion of the beauty of God as the 'object' of religious melancholy, where he refers to the Latin translation by Giovanni Carlo Saraceno of the Dialoghi d'amore of Leone Ebreo: 'for love presupposeth knowledge, faith, hope,

\footnotetext{
42 Urbanus Rhegius, Opera ... Latine edita, 2 vols (Nuremberg, 1562), 1. 343.

43 Although Burton did not cite Rhegius anywhere in the Anatomy, and his library did not contain any Rhegius's works, he had access to the 1562 Latin Opera in the Bodleian (R 2.8 Th.; Thomas James, Catalogus universalis librorum in Bibliotheca Bodleiana [Oxford, 1620], 417). It remains difficult to explain the reference to Jacobus de Voragine, but Burton may have mixed up his notes from Urbanus with some taken from Voragine's discussions of marriage in Sermones quadragesimales (Venice, 1575), ff. $175 \mathrm{v}, 197 \mathrm{v}-198 \mathrm{r}$.

${ }^{44}$ Francis Hastings, Apologie or defence of the watch-word (London, 1610), 64. Burton owned a copy of Hastings's $A$ watchword to all religious, and true hearted English-men (London, 1598): Kiessling, The Library of Robert Burton, no. 757; the Apologie or defence was a riposte to the criticisms of this earlier work by the notorious Jesuit controversialist Robert Parsons. The phrase is also used in John Darrel, A detection of that sinnful, shamful, lying, and ridiculous discours, of Samuel Harshnet ... (n. p., 1600), 199, where it is attributed just to 'the Poet'.

45 The Unabridged Acts and Monuments Online or TAMO (1570 edition) (HRI Online Publications, Sheffield, 2011) $<\mathrm{http} /$ /www.johnfoxe.org > accessed 24 January 2018; VIII,1423, where Democritus is also mentioned.

46 The Unabridged Acts and Monuments Online or TAMO (1563 edition) (HRI Online Publications, Sheffield, 2011) $<$ http//www.johnfoxe.org > accessed 24 January 2018; V, 1424. Foxe (or more likely his source) may have confused the Roman poet Calpurnius with the humanist philologist Johannes Calphurnius (1443-1503), who produced an edition of Terence's Heautontimorumenos (Venice, 1476), as well as a commentary on the play (Vicenza, 1477); but the attribution of the phrase to Horace remains mysterious.

${ }^{47}$ By the time Burton wrote the Anatomy the phrase 'pleno ridet Calphurnius ore' was also in circulation on the continent; it is quoted, for example, by the Portguese Jurist Francisco de Caldas Pereira in his Analyticus Commentarius (Frankfurt, 1618), 66b.
} 
and unites us to God himselfe, as Leon Hebreus delivereth unto us, and is accompanied with the feare of God, humility, meeknesse, patience, all those vertues, and charity it selfe'. A marginal note attached to 'Leon Hebreus' reads 'Dial. 1. Omnia convertit amor in ipsius pulchri naturam' (3. 4. 1. 1; III, 336). The Clarendon commentary traces the passage in the main text to fols 38vff. in the 1564 edition of the Latin De amore, where the first dialogue indeed describes the manner in which love may unite man to God, and Bamborough translates the Latin given in Burton's note as 'Love converts everything to its own beauty' (VI, 212). This is not a quotation from the $D e$ amore, however, and although the first dialogue discusses knowledge as a precondition for love of (and unity with) God, it does not mention faith or hope in this context. ${ }^{48}$ This passage actually requires more careful treatment. The phrase 'Omnia convertit ... naturam' is a modified quotation from Marsilio Ficino's translation of the commentary on Plato's Alcibiades by Proclus, where the questions are raised of where the divine love (amor Deus) 'appeared in the beginning', how it 'proceeds to all things', and 'with what monads' (unitates, corresponding to the $\mu$ ová $\delta \varepsilon$ of Proclus) 'did it come into being'? ${ }^{49}$ Proclus explains, in Ficino's translation, that 'amongst the intelligible and hidden gods' there are three substances (substantiae): the first imprinted by the good, the second marked by wisdom, and the third defined by beauty,

... where is the most beautiful of the intelligibles, as the Timaeus says. Three monads arise that accord to these intelligible causes, and exist causally and uniformly in them: faith, which fixes everything in the good; truth, which exhibits all knowledge of beings, and lastly love, which turns back everything and joins it to the nature of the beautiful itself (amor denique convertit omnia congregatque in ipsius pulchri naturam). ${ }^{50}$

This raises a difficulty with implications for the literal sense of the text of the Anatomy. The concern of Proclus is to identify the role of love in the return to divine beauty, and the

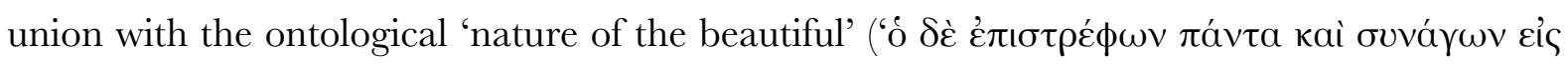

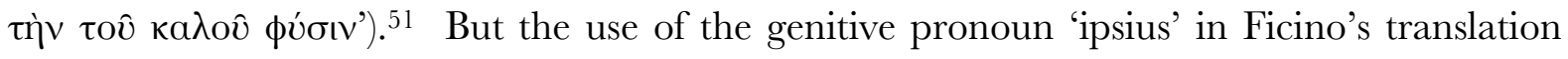
creates a grammatical ambiguity with regard to its object (now either the substantive adjective pulchri or the noun amor), and introduces the alternative possibility (unintended by Proclus and

\footnotetext{
48 The role of hope is briefly discussed in the third dialogue: Leone Ebreo, De amore Dialogi Tres, tr. Giovanni Carlo Saraceno (Venice, 1564), ff. 217v-218r, 291v-292r, 383r-v.

49 Ficino, Opera, 1910: 'Ubinam igitur extitit ab initio? Quo pacto per universa procedit, \& quibus cum prodiit unitatibus?',

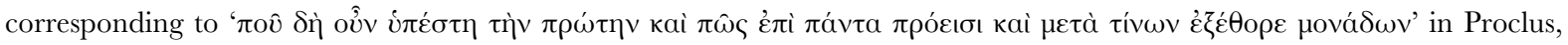
Commentary on the First Alcibiades, ed. L. G. Westerink, tr. and comment. William O'Neill (Dilton Marsh, 1965), 51. 7-8, 65. Dodsworth lists five other references to this work in the Anatomy in the biobibliography at VI, 407.

${ }^{50}$ Ficino, Opera, 1910: 'Cum igitur tres sint in diis intelligibilibus, occultisque substantiae, \& prima quidem obsignata sit bono, ipsum videlicet bonum ex se intelligens, ubi sicut sacra eloquia tradunt, unitas est paterna: secunda vero per sapiens designetur, ubi prima viget intelligentia: tertia per pulchrum definiatur, ubi intelligibilium est pulcherrimum, ut Timaeus ait, nimirum \& tres secundum has intelligibiles causas unitates existunt, secundum causam quidem uniformiter in intelligibilibus consistens, effulgentes vero primum in ipso ineffabili deorum ordine scilicet fides, veritas, amor. Fides quidem omnia firmat in bono. Veritas autem omnem in entibus cognitionem explicat, amor denique convertit omnia congregatque in ipsius pulchri naturam'. 51 Proclus, Commentary on the First Alcibiades, 52. 1-2, 65.
} 
Ficino) that amor returns everything to itself. In Burton's quotation, the omission of 'congregatque' removed the reference to the return to the divine, and may well have been a factor in drawing Bamborough to the latter reading and a translation of 'convertit ... in' as 'converts to'. But rendering 'convertit' as 'turns back' or 'returns to' is clearly preferable for two reasons. First, it conforms to the typical usage of $\dot{\varepsilon} \pi \_\tau \rho \varepsilon \dot{\phi} \omega$ in Neoplatonist philosophy, where this verb refers to the return of the soul to the One, and is often rendered by Ficino into Latin as converto. ${ }^{52}$ And second, this translation fits with the context in which the quotation appears in the Anatomy, where the return to the One appears in heavily Christianized terms as a reunion with God accompanied by various spiritual virtues. Whilst this passage in Proclus mentions faith, it does not include the other virtues, but Burton's imperative here is clearly to harmonize the Neoplatonist account of love found in Leone and Proclus with Christian ethics. ${ }^{53}$

Other lacunae in the Clarendon commentary apparently stem from the inherent difficulty of tracing passages taken from authors and works that are now quite obscure, and where Burton's decision to leave many of his quotations unattributed implicitly challenges us to find their source. For instance the phrase 'qui de me forsan, quicquid est omni contemptu contemptius judicant' (DJR; I, 14), which is unidentified by Bamborough and Dodsworth (IV, 32), is taken and slightly adapted from Ulrich von Hutten's preface to his poem 'Nemo' - a work that reappears conspicuously later in the preface (DJR; I, 107). ${ }^{54}$ The third Partition contains several similar cases. The phrase 'Benefacit animae suae vir misericors', which appears in a note attached to Burton's observation 'how gratious ... a charitable man is in Gods eyes' (3. 1. 3. 1; III, 38), is the first half of Proverbs 11:17 in the Latin Vulgate. ${ }^{55}$ Two lines of verse in the account of 'How Love tyrannizeth over Men', ‘__ Sed amor, sed effraenata libido, / Quid castum in terris intentatumque reliquit.?' (3. 2. 1. 2; III, 55), have been extracted from the Umbra (1595) of Thomas Campion. ${ }^{56}$ The Latin terms in Burton's description of how the mistress of the poet Giovanni Pontano 'was the cause of his Roses, Violets, Lillies, Nequitiae, blanditiae, joci, decor, Nardus, Ver, Corolla, Thus, Mars, Pallas, Venus, Charis, Crocum, Laurus, Unguentum, Costum, Lachrymae, Myrrha, Musae, $E^{2}$ c. and the rest of his Poems' (3. 2. 3. 1; III, 193-4) are taken from the criticisms made by Julius Caesar Scaliger, in his Poetices libri septem (1561), of the tedious verbal repetitiveness of Pontano's Tumuli (1505).57 The racy verse quotations ('Flammeolos oculos collaque lacteola' and

\footnotetext{
${ }^{52}$ See, for example, Plotinus, Enneads, 5. 1. 1, 5. 2.1 (Ennead V, tr. A. H. Armstrong [Cambridge, MA and London, 1984], 12, 58), translated by Ficino in Plotinus, Operum philosophicorum omnium libri LIV in sex Enneades, tr. and comment. Marsilio Ficino (Basel, 1580), 482. My translation of 'Omnia convertit amor in ipsius pulchri naturam' is therefore 'love returns everything to the nature of the beautiful itself'.

${ }^{53}$ See Stephen Clucas, 'Italian Renaissance Love Theory and the General Scholar in the Seventeenth Century', in Cecilia Muratori and Gianni Paganini (eds), Early Modern Philosophers and the Renaissance Legacy (Dordrecht, 2016), 41-58.

${ }^{54}$ Ulrich von Hutten, Opera poetica (Frankfurt, 1538), sig. Q [7r].

55 Swift Edgar and Angela M. Kinney (eds), The Vulgate Bible, vol. 3: The Poetical Books. Douay-Rheims Translation (Cambridge, Mass. and London, 2011), 598.

56 Thomas Campion, Poemata. Ad Thamesin. Fragmentum Umbrae. Liber Elegiarum. Liber Epigrammatum (London, 1595), sig. Cijr; a later version is in Thomas Campion, Epigrammatum libri II. Umbra. Elegiarum liber unus (London, 1619), sig. E12r, and now in Hubert Wilson Hawkins (ed.), Thomas Campion's Complete Latin Works: Critical Text and Translation (Charlottesville, VA, 2017), p. 96, 11. 71-2. These sources have 'ineffraenata' rather than 'effraenata', but this does not affect the meaning.

${ }^{57}$ Julius Caesar Scaliger, Poetices libri septem (Lyon, 1561), VI, 312b.
} 
'Lumina sint Melitae Junonia, dextra Minervae, / Mamillae Veneris, sura maris dominae, Ėc.') added by Burton to the second edition to amplify one of his descriptions of physical beauty and attributed in a marginal reference to 'Luc. Brugensis or. reliquis', which caused Bamborough to remark that 'it seems barely credible that they can be from so sober biblical exegete as Lucas Brugensis' (VI, 145) - also known as Frans Lucas van Brugge or François Luc de Bruges (1549-1619) - are actually from another Lucas Brugensis, the humanist scholar from Bruges also known as Lucas Fruterius, or Lucas Fruytier (1541-1566). Both quotations are translated fragments from the ancient Greek epigrammatist Rufinus, which Fruterius collected in his two volumes of Reliquiae (1584). ${ }^{58}$ Two additions to the fourth edition, both inserted in the last Subsection on the cure of love melancholy, can also be identified: '—_ captare viros \& spernere captos', referred in a note to 'T. H.' (3. 2. 5. 5; III, 247), and which is an excerpt from a line of the De mirabilibus Pecci (1627) by Thomas Hobbes, a copy of which had been given to Burton by the author; ${ }^{59}$ and 'Hippolite nescis quod fugis vitae bonum / Hippolite nescis ——', which Burton added to a passage already containing two quotations from Seneca's Phaedra (3. 2. 5. 5; III, 262-3). The new addition, which Bamborough notes is not from Seneca (VI, 167), comes from the supplementary scenes for the Phaedra written by the poet and playwright William Gager. They had been included in a performance of the play at Christ Church, where Gager had been a Student, in 1592.60 Turning, finally, to the Section on religious melancholy, the verses used to illustrate the idea of divine vengeance, 'Assequitur Nemesisque virum vestigia servat, / Ne male quid facias. $\longrightarrow$ ' (3. 4. 2. 3; III, 418), are found in the Emblemata of Andrea Alciato, accompanying emblem no. 27 ('Nec verbo, nec facto quenquam laedendum'). ${ }^{61}$ The line 'tot solatia in hac aegri orbis calamitate mortalibus taediis Deus objecit', added by Burton in defence of 'hauking and hunting' in the fifth edition and attributed to 'Vandormilius de Aucupio cap. 27' (3. 4. 1. 4; III, 391), is taken from the Oblectatio vitae rusticae (1633) by the Pomeranian author Aegidius van der Myle. ${ }^{62}$

Elsewhere in the Clarendon edition, slips by the commentators and textual editors have some unfortunate knock-on effects that obscure Burton's creative way with quotations. Glossing his remark about a man of high social station that 'dispossesse him of his wealth, [he] is a funge' (a fool), and the accompanying note, 'Send them both to some strange place naked, ad ignotos, as Aristippus said, you shall see the difference. Bacons Essayes' (2. 3. 2. 1; II, 141-2),

\footnotetext{
${ }^{58}$ Lucas Fruterius, Librorum Qui recuperari potuerunt Reliquiae. Inter quos verisimilium Lib. II. Et versus miscelli, vol. 1 (Lyon, 1584), 160, 161. The second fragment is given as 'Lumina stant Melitae Funonia, dextra Minervae, / Mammiculae Veneris, sura maris dominae'.

59 Thomas Hobbes, Ad nobilissimum dominum Guilielmum Comitem Devoniae, Ẽc. De Mirabilibus Pecci, Carmen Thomae Hobbes (London, 1627); Kiessling, Library of Robert Burton, no. 818. The quotation is at sig. A2r.

60 The new scenes were printed in William Gager, Meleager. Tragoedia nova (Oxford, 1592); the quotation is at sig. F4v. On Gager's activities at Christ Church see Dana F. Sutton (ed. and trans.), William Gager: The Complete Works, vol. 1 (New York and London, 1994), xii, xiv, xxiii; in this edition the passage quoted by Burton is at vol. 2, 208.

Henry L. Thompson, Christ Church (London, 1900), 42.

61 Andrea Alciato, Emblemata, ed. Claude Mignault (Paris, 1602), XXVII, 186. The verses are based on Anthologia Graeca XVI, nos 223-4 (Hermann Beckby (ed.), Anthologia Graeca, Band IV, Buch XII-XVI (Munich, 1965), 422).

62 Aegidius van der Myle, Oblectatio vitae rusticae (Stettin, 1633), ch. 21, 195, where the passage is given as 'totq[ue] solatia in hac aegri Orbis calamitate, mortalitatis taediis objecit'. Burton owned a copy of this book (Kiessling, Library of Robert Burton, no. 1106), but in the Clarendon biobibliography (VI, 430), Dodsworth fails to identify 'Vandormilius', which would be more helpfully printed as 'Vandermilius' or 'Vandermylius'.
} 
Bamborough refers to Bacon's Essay XIV, 'Of Nobilitie' (V, 221). In fact Burton has taken this from Essay XXII, 'Of Cunning', ${ }^{63}$ and the mistake occludes the manner in which he has manipulated his source: in the relevant passage in 'Of Cunning', Bacon's observation is that the 'old rule, to know a Foole from a Wise Man; Mitte ambos nudos ad ignotos, et videbis' does not hold for cunning men, whose judgement fails when they are presented with unfamiliar people; Burton has redirected the critical observation against the vanity of the nobility. ${ }^{64}$ A similar accident occurs in the 'Digression of the Misery of Schollers', where the editors' initial reliance on the 1632 edition as the basis for the Clarendon copy-text reproduced a misplaced reference marker, attached correctly in the second and third editions to a quotation from Buchanan's Franciscanus but migrated erroneously in the fourth to a previously unattributed Latin couplet and verse translation: 'Dat Galenus opes, dat fustinianus honores, / Sed genus \& species cogitur ire pedes: /The rich Physitian, honor'd Lawyers ride, / Whil'st the poore Scholler foots it by their side' (1. 2. 3. 15; I, 310). ${ }^{65}$ The change is recorded in the textual notes (III, 587), but the error remained in the first edition of the Clarendon reading text, and although it was remedied in later reprints, ${ }^{66}$ it seems to have led Bamborough to overlook the couplet and its translation. Yet here again we see the creative aspect of Burton's quotational habit. As Scoggin points out, the saying, of obscure origin, was commonplace in Renaissance learning; it more usually appeared as 'dat Galenus opes et sanctio Justiniana / ex aliis paleas, ex istis college grana' ('Galen brings riches and Justinian honours; from the others you gather chaff, from these two grain'), but was often adapted. ${ }^{67}$ The second line of Burton's version, which gives 'genus $\mathcal{E}^{2}$ species' where others have 'Aristoteles', ${ }^{68}$ might have amused his learned contemporaries, and the implied association of logic-chopping with scholarly misfortune in his verse translation reinforces a theme pursued later in the 'Digression' (1. 2. 3. 15; I, 324). The issue recurs, prompted by a more knotty textual problem, in the third Partition, where a marginal quotation from Robert Tofte's Blazon of jealousie (1615) omitted in the 1624 edition - probably by the compositor, who presumably struggled with Burton's extensive reworking of the text at this point (3. 2. 3. 1; III, 152) - is also ignored by Bamborough in his commentary. ${ }^{69}$

\footnotetext{
63 The attribution of the saying to Aristippus originates in Diogenes Laertius (2.73), but in its first appearance in the Anatomy no mention is made of this (Burton, The Anatomy of Melancholy [Oxford, 1621], 393). Burton seems to have subsequently traced it to Diogenes Laertius (The Anatomy of Melancholy [Oxford, 1624], 262), which in the revised translation of Ambrogio Traversari given in De vitis, dogmatis \& apophthegmatis eorum qui in philosophia claruerunt, libri X (Paris, 1570), 69, reads 'Interrogatus quid differat sapiens ab insipiente, Mitte, ait, ambos nudos ad ignotos, \& disces'. The unrevised Traversari translation has 'incognitos' rather than 'ignotos' (Diogenes Laertius, De vita \& moribus philosophorum [Florence, 1490], sig. c6v).

${ }^{64}$ Francis Bacon, The Essayes or Counsels, Civill and Morall, ed. and comment. Michael Kiernan (Oxford, 1985), 69-70.

65 Burton, Anatomy (1621), 174; Anatomy (1624), 116; Anatomy (1628), 123; Anatomy (1632), 131; the mistake persists in Anatomy (1638), 133 and Anatomy (1651), 133, and was detected in G. C. Scoggin, 'A Popular Commonplace', Classical Philology, 14 (1919), 386-89, at 386.

66 The error is in the 1989 printing; corrected reprints were issued in 1992, 1994, 1995, and 1997.

67 Scoggin, 'A Popular Commonplace'; Ian Maclean, Logic, Signs and Nature in the Renaissance: The Case of Learned Medicine (Cambridge, 2000), 85.

68 Scoggin, 'A Popular Commonplace', 387, 389.

69 The quotation ('Love is a fiend ... repentance dwell') is taken by Tofte, without acknowledgement, from the poet Richard Barnfield: Robert Tofte, The blazon of jealousie ... (London, 1615), 3, note 1; Richard Barnfield, The affectionate shepheard ... (London, 1594), sig. F4r. It appears attributed to 'R. T.' in Burton, Anatomy (1621), 602, but dropped out of the expanded
} 
Many frustrating puzzles about the sources of the quotations in the Anatomy remain, although we can speculate further about some of these. In a passage of untranslated Latin deemed unsuitable for vernacular readers, Burton discusses medical views about beneficial and detrimental times for engaging in sexual intercourse, and after noting the sickliness of those conceived on the fourth day of the moon, he adds the perplexing coda 'ad laborem nati, si saniores, inquit Eustathius, ut Hercules, \& alii' (1. 2. 1. 6; I, 208). Bamborough's suggestion (IV, 255) that Burton may have been thinking of the medical astrology in De vitae humanae ... prorogatione (1589) by Ferdinando Eustachi (Eustachius) is unsatisfactory, not least because it contains no reference to Hercules or the phrase 'ad laborem nati'. The Homeric commentaries of Eustathius of Thessalonica seem likely candidates, but I have been unable to find a satisfactory locus there. One possible source, however, is book 4 of the Rerum ungaricarum decades quatuor by Antonio Bonfini (Bonfinius), which contains a similar passage in its record of a speech given by Matthias Corvinus ('Generosi viri est, more Herculis, in perpetuo labore, \& sudore versari. Non ad ventrem, \& desidiam, sed ad laborem nati sumus'), ${ }^{70}$ and was quoted elsewhere in the Anatomy (DJR; I, 97). ${ }^{71}$ This would leave Burton's attribution to 'Eustathius' unexplained, however. Perhaps, having used Eustachi's work in the immediately preceding medical discussion without acknowledgment, the physician's name then crept into the clause on Hercules.

Elsewhere the Anatomy presents text in italics as if it were a quotation from a single published source, when it may well have been a phrase freely circulating in the learned discourse of Burton's humanistic environment. This seems to be the case for Burton's description of lawyers in the preface as 'our common hungry Pettefoggers, rabulas forenses' (DJR; I, 71). Bamborough and Dodsworth (IV, 113) suggest a cross-reference to Cicero, De oratore 1.46.202, which provides the disparaging terms 'causidicum' and 'clamator' alongside 'rabula', ${ }^{72}$ but the phrase 'rabulae forenses' - it appears in the nominative in the first edition of the Anatomy ${ }^{73}$ - can be found in The Lawiers Logike (1588) by Abraham Fraunce. ${ }^{74}$ However, it is also present in Philipp Melanchthon's Loci communes (1521), ${ }^{75}$ and in Claude Mignault's commentary on Alciato's Emblemata (1573), ${ }^{76}$ both of which are used elsewhere in the Anatomy. Given the lack of a specific reference in the text, he seems equally likely to have picked it from

\footnotetext{
discussion presented in Anatomy (1624), 404-5 and all subsequent versions, though it is included the Clarendon textual notes (III, 597). Given that Burton removed substantive material only rarely, and usually for an obvious reason, the compositorial error should be corrected and the note restored to the reading text.

70 Antonio Bonfini, Rerum Ungaricarum decades quatuor cum dimidia (Hanover, 1606), IV. 2, 551.

71 Burton, Anatomy (1651), 67, where 'Hungar. dec. 1. lib. 9.' is given as the reference; this is untraced in the Clarendon commentary (IV, 148), but it is a loose paraphrase of IV. 9, 679 in the 1606 edition of Bonfini's work (see also p. 830).

72 Cicero, On the Orator: Books 1-2, tr. E. W. Sutton and H. Rackham (Cambridge, MA, 1942), 140.

73 Burton, Anatomy (1621), 48; in the macaronic prose, the subsequent lapse into the accusative is defensible ('I meane ... rabulas forenses').

74 Abraham Fraunce, The Lawiers Logike ... (London, 1588), sig. ๆ4r.

75 Philipp Melanchthon, Loci communes rerum theologicarum seu hypotyposes theologicae, in Opera quae supersunt omnia, ed. Carolus Gottlieb Bretschneider, vol. 21 (Halle, 1834-60), col. 201.

76 Andrea Alciato, Emblemata, comment. Claude Mignault, 2nd edn (Antwerp, 1577), 518.
} 
memory out of the contemporary literary ether. ${ }^{77}$ A similar point probably holds for 'lusty Laurence' and the description of 'Messalina the Empresse' as 'prostibulum foeminae', both added to a list of the temperamentally lascivious in the third edition (2. 2. 2. 1; II, 32). The former is easily identified as the eponymous protagonist of a traditional English ballad, now lost, about a lascivious womaniser. ${ }^{78}$ But the misogynistic phrase 'prostibulum foeminae' is harder to track. Bamborough suggests a reworking of the phrase 'prostibulum popli' from Aulularia 285 (V, 107), but the exact wording can be found in a comedy by Edmund Stubbe, Fraus honesta, which was first performed at Trinity College, Cambridge in 1619 (and revived in 1629). ${ }^{79}$ Unless we suppose, though, that Burton attended the first performance, or had read one of the manuscripts held in Cambridge, it is difficult to claim this as the source, since the play was not published until 1632. ${ }^{80}$ It seems more likely that he was recalling a phrase circulating amongst those with an interest in Latin comedy and satire. In the absence of a better explanation, this is a case where this particular reader must acknowledge his limits.

\section{Persons.}

I turn now to historical persons and authors mentioned in the Anatomy. Burton often assumed that his readers needed (or wanted) no assistance here, but whilst some of those left unidentified in the Clarendon biobibliography and indexes may have been fairly well-known to his learned contemporaries, others seem likely to have tested even the cognoscenti. Two newly identified authors of differing fame, Thomas Hobbes and Aegidius van der Myle, have been covered in the previous section, and four more can be added. The first is Pietro Torrigiano de' Torrigiani (d. ca. 1319), a celebrated Florentine physician whose name was Latinized variously: Burton rejects the spelling 'Crusianus' given by Johannes Trithemius in favour of Gesner's 'Drusianus' (DJR; I, 22), but he was also known as Turisanus and Trusianus. ${ }^{81}$ The second is a shadowy figure even by the fairly high standards of the Anatomy: 'Udalinus Leonorus' (2. 4. 2. 3; II, 235), whose correspondence with Pietro Andrea Matthioli is included in the latter's Epistolae medicinales (1564), and who is probably the physician Udalricus (or Ulricus) Leonorus à Kauba, a Bohemian (not German [VI, 375]) graduate of Padua. ${ }^{82}$

Establishing the identity of two authors mentioned in the discussion of the therapeutic utility of poetic composition in 'Exercise Rectified of Body and Minde' (2. 2. 4. 1; II, 94) is less

\footnotetext{
77 Other citations of these works are listed at VI, 300, 384 in the Clarendon commentary.

78 Gordon Williams, A Dictionary of Sexual Language and Imagery in Shakespearean and Stuart Literature, Volume I A-F (London and Atlantic Highlands, NJ, 1994), 833-4, referring to details of the ballad given in Hyder Edward Rollins, An Analytical Index of the Ballad-Entries [1557-1709] in the Register of the Company of Stationers of London (Hatboro, PA, 1967), 1607-9.

79 Alan H. Nelson, Records of Early English Drama: Cambridge, vol. 2 (Toronto and London, 1989), 896.

${ }^{80}$ Edmund Stubbe, Comoedia Cantabrigiae olim acta (London, 1632); the quotation is at p. 44.

81 Nancy G. Siraisi, Medicine and the Italian Universities 1250-1600 (Leiden, Boston and Köln, 2001), 169-71, 174-5.

82 The name is properly given as 'Udalricus Leonorus' in Pietro Andrea Mattioli, Epistolarum medicinalium libri quinque (Lyon, 1564), 367. Some information about Udalricus Leonorus is given in Jaroslav Kolár, 'Z mládí Václava Březana', Česká literatura, 24 (1976), 47-52, at 47-8; see also Albert Mays and Karl Christ, Neues Archiv fir die Geschichte der Stadt Heidelberg und der rheinischen Pfalz, vol. 1 (Heidelberg, 1890), 135.
} 
straightforward. In the first edition, Burton recommends that 'rather then doe nothing', a man can usefully 'vary a Verse a thousand waies, as Putean hath done';33 as Bamborough notes (VI, 186), a side note reproduces a line ('Tot tibi sunt dotes virgo quot sidera coelo') that is given 1,022 variations by the Jesuit poet Bernardus Bauhusius in a volume edited in 1617 by the Flemish humanist Erycius Puteanus. ${ }^{84}$ In the third edition more text and references appear: 'so torturing his wits, or as Rainnerus of Luneburge, 2150 times in his Proteus poeticus, or Scaliger, Chrysolithus, Cleppisius, and others have in like sort done', with another marginal quotation, ' $D a$ pie Christe Urbi bona sit pax tempore nostro' ${ }^{85}$ The Clarendon commentary equivocates between the elder Julius Caesar and the younger Joseph Justus Scaliger (V, 186), and identifies Cleppisius (with a tentative question-mark) as the German epigrammatist Gregor Kleppis (VI, 334), ${ }^{86}$ leaving 'Rainnerus of Luneberg' and 'Chrysolithus' unidentified, and the new line of verse untranslated and ignored. The spelling of 'Rainnerus' is misleading: in the revised Bibliotheca classica (1625), Georg Draud includes a work by Henricus Reimarus (Heinrich Reimers, from Lüneburg), entitled Proteus Poeticus, hoc est, Praecatiuncula metrica, novem verborum annum Christi continentium, in 2150. formas conversa, published in Hamburg in 1619.87 I have been unable to consult this, but it is discussed by Florian Cramer in his survey of seventeenth-century 'Proteusvers-Dichtung', which refers to its variations of the verse 'Da pie Christe Urbi bona pax sit tempore nostro'. ${ }^{88}$ Cramer also quotes its unpaginated preface: 'Symbolus est, Verbum et / Versus utrumque notant / Multi sit multis, qui Verbo: sed mihi docto / Qui versu ludit PROTEA, pluris erit / SCALIGER hunc docuit, finxit BAUHUSIUS, auxit / CHRYSOLITHUS metricis CLEPSIUSq[ue] modis. / REIMARE, his tantis minor esse putere Magistris?'89 This, I suggest, is the source of Burton's references to 'Rainnerus' and the verse 'Da pie ... nostro'; to Scaliger, the elder, who was the first to use the name 'Proteus' for combinatorial verses of this kind in his Poetices libri septem, ${ }^{90}$ and was seen as the greatest authority on the subgenre; to Cleppisius (Gregor Kleppis), whose own Proteus poeticus was published in $1617 ; 91$ and finally to the mysterious 'Chrysolithus'.

The latter is perhaps one of the most obscure figures in the whole of the Anatomy. I have found no poets explicitly using the name of 'Chrysolithus', which is presumably a male alias, and no discussion of his identity. A medieval Carmelite theologian, Johannes Goldestonus

\footnotetext{
83 Burton, Anatomy (1621), 355.

84 Erycius Puteanus, Pietatis thaumata in Bauhusii Proteum Parthenium unius libri versum, unius versus librum, stellarum numero, sive formis MXXII variatum (Antwerp, 1617).

85 Burton, Anatomy (1628), 264.

86 It is wrongly indicated, however, that the reference was added in the second edition.

87 Georg Draud, Bibliotheca Classica. Sive Catalogus Officinalis ..., vol. 2 (Frankfurt, 1625), 1581.

88 Florian Cramer, Exe.cut[up]able statements. Poetische Kalküle und Phantasmen des selbstausführenden Texts (Paderborn, 2011), 70-77, at 71. The verse contains a chronostichon indicating its year of composition: MDCXVIIII ('Da pIe ChrIste, VrbI bona paX sIt teMpore nostro').

89 Cramer, Exe.cut[up] able statements, 71. I am unable to verify whether 'Clepsiusque' is a mistranscription of 'Clepisiusque' in the original.

90 Scaliger, Poetices libri septem, II. 30, 73.

91 Gregor Kleppis, Proteus poeticus (Lepizig, 1617); Scaliger and Bauhusius are mentioned in the dedicatory epistle at sig. A2v.
} 
(Jean Goldeston) did, however, use the name 'Johannes Chrysolithus', which suggests an etymological solution to the puzzle. ${ }^{92}$ 'Chrysolithus' is the Latin term for the gemstone chrysolite, which is sometimes goldish-green - hence the derivation from the Greek $\chi \rho \bar{v} \sigma o ́ \varsigma$ (gold) and $\lambda i^{\prime} \theta$ os (stone); the Latin prefix 'chrys-' is also commonly used in Renaissance alchemy ('chrysographia', 'chrysopoeia', 'chrysopraxia', etc.). ${ }^{93}$ Given our suspect's likely penchant for linguistic gameplay, and probable location in the Low Countries or Germany, it seems plausible to suppose that his real name may have been 'Goldstein'. And this conjecture is confirmed by the correspondence of Leibniz. In a letter to the Zwickau poet and philologist Christian Daum written in March/April 1666, Leibniz relates his De arte combinatoria to Daum's own 'Protean' verse experiments, and mentions that he has heard of a book by a certain 'Goldstein'. In his reply, Daum reports that he has not managed to get hold of it, but that he once saw a similar one by Cleppisius. ${ }^{94}$ The work in question is the Versum quem Protea Poeticum vocant by Carol Goldstein, issued in Leipzig in 1618 by Elias Rehefeld and Johann Grosse (also the publishers of Cleppisius), and which presents 1,618 variations of the verse 'Ars non est: Tales bene structos scribere versus', followed by 26 more, as the author says, to make up for any that may have been omitted by the printer. ${ }^{95}$ Since Goldstein does not refer to himself as 'Chrysolithus' anywhere in this work, Burton presumably took the reference from Reimarus, possibly in ignorance of the real name of this little-known combinatorial poet. ${ }^{96}$

\section{Places.}

Another set of challenges posed by the Anatomy, on the whole met admirably in the Clarendon commentary, is presented by its frequent geographical references, often to countries, cities, or landmarks no longer in existence or more commonly known by different names. Again, most of these would have been easily recognized by Burton's learned readers, though some would surely have presented some difficulty. Nine more can now be identified, the first six of which are relatively straightforward. The wall at 'Schaenunte' built by the Peloponnesians, first mentioned by Burton in the third edition (DJR; I, 83) is, as Strabo explains in his description of the Saronic Gulf (8. 6. 4, 22), the location where the roadway built across the Isthmus at Corinth terminates: 'Exorvov̂s' (Schoinous), located to the east of Corinth and north of Cenchreae, and now known as Kalamaki. ${ }^{97}$ The two places in Poland, called by Sebastian

\footnotetext{
92 Claudia Fabian, Personennamen des Mittelalters. Personal Names of the Middle Ages. Nomina Scriptorum Medii Aevi (Berlin, 1999$), 396$.

93 René Hoven, Lexique de la prose latine de la Renaissance / Dictionary of Renaissance Latin from Prose Sources, $2^{\text {nd }}$ edn (Leiden and Boston, 2006), 92.

${ }^{94}$ Gottfried Wilhelm Leibniz, Sämtliche Schriften und Briefe (1663-1685), ed. Leibniz-Forschungsstelle der Universität Münster (Berlin and Boston, 2014) (pubd online June 2004) <https://www.degruyter.com/view/product/218736> accessed 12 February 2018; 9, 11. Daum also refers here to the Proteus Poeticus of Reimarus.

95 Carol Goldstein, Versum quem Protea Poeticum vocant evulgo 1644 numeris absolutum (Leipzig, 1618).

96 The book is not listed in Kiessling's catalogue of Burton's library, was not held in the Bodleian, and is today unavailable in any public library in the UK. A reproduction of the copy held in the Bayerische StaatsBibliothek in Münich is available online (<http://reader.digitale-sammlungen.de/de/fs1/object/display/bsb10926418_00005.html> accessed 12 February 2018).

97 The Geography of Strabo, tr. Horace Leonard Jones, vol. 4 (London and Cambridge, MA, 1968), 154-5, 196-7.
} 
Munster in his Cosmographia 'Nochouu' and 'Paluky' and by Burton in his second edition 'Nokow and Palukye' (2. 2. 3. 1; II, 37), where pots strangely fashioned by nature to resemble crowns and various living creatures were reportedly excavated, are probably the central Polish villages known now as Nochowo, just south of Poznań, and Pałuki, north of Warsaw and to the east of Ciechanów. 98 The 'famous gardens of the Lord Chantelou in France' (2. 2. 4. 1; II, 73), which as Bamborough notes (V, 167) are described by Burton's source, the Itinerarium Galliae (1617) of Jodocus Sincerus, as being somewhere near Chartres, ${ }^{99}$ were located at the now sadly derelict Château de Chanteloup, a property of the Neufville family at Saint Germain-lès-Arpajon in the Essonne. The legendary topiary gardens were celebrated in humanist circles, and were the subject of the poem Cantilupum (1587), probably by Madeleine de L'Aubespine Villeroy. ${ }^{100}$ Burton's peculiar description of 'that Marrhusian Phaedrus' (3. 2. 2. 2; III, 89) may have been intended as a reference to Maurusia (the Greek name of Mauritania), but is more likely to be an accidental corruption of the name given in his source, Ficino's Commentarium in Convivium Platonis de amore (1484), where Phaedrus is identified as 'Myrrhinusium' to indicate his birthplace in the deme of Myrrhinus in Attica, near modern Merenda. ${ }^{101}$ 'Narsinga' (3. 4. 1. 1; III, 341) was not, as Bamborough speculates, Narsinghpur (VI, 214), but the Empire of Vijayanagara, sometimes known as the kingdom of 'Bisnegar' (also 'Bisnagar' or 'Bisnaga'), but whose Portuguese name 'Narsinga' was often used in early modern English sources. ${ }^{102}$

Two other locations mentioned in the Anatomy are harder to pin down. One of passages added to the discussion of 'Terrestrial Divels' in the 'Digression of Spirits' in the second edition relates that '[n] eere Rupes nova in Finland, in the Kingdome of Sweden, there is a Lake, in which, before the Governour of the Castle dyes, a spectrum in the habit of Arion with his Harpe appeares, and makes excellent musicke' (1. 2. 1. 2; I, 188). This is is taken from the Magiae omnifariae theatrum (1606) of Strozzi Cicogna. ${ }^{103}$ Neither Cicogna nor Heinrich Kornmann, who also

\footnotetext{
98 Sebastian Munster, Cosmographiae universalis lib. VI (Basel, 1572), p. 871.

${ }^{99}$ Jodocus Sincerus, Itinerarium Galliae (Strassburg, 1617), 45-56.

100 See Perrine Galand, 'Être parlementaire et poète en France dans la seconde moitié du XVIe siècle', Humanistica Lovaniensia, 61 (2012), 3-25. The gardens are also praised in Claude Mignault, Cai. Plinii Secundi Epistolae. Adiectae Notae, E̊ emendationes (Paris, 1608), ff. 4lv-43r.

${ }^{101}$ Ficino, Opera, vol. 2, 1358. See Hans Lohmann, 'Myrrhinus', in Hubert Cancik and Helmuth Schneider (eds), Brill's New Pauly (pubd online 2006) <http://dx.doi.org/10.1163/1574-9347_bnp_e814530> accessed 13 March 2018.

102 The Suma Oriental of Tomé Pires, ed. and tr. Armando Cortesão, 2 vols (London, 1944), 1. 63-5. In English sources, see Robert Stafford, A geographicall and anthologicall description of all the empires and kingdomes ... (London, 1607), 55; Samuel Purchas, Purchas his pilgrimage ... (London, 1613), V.11, 423-4. 'Bisnegar' and 'Narsinga' were sometimes used interchangeably, but for the Portuguese the former usually referred to the capital of Narsinga: Fernão Lopes de Castanheda, História do descobrimento $\mathcal{E}$ conquista da India pelos portugueses, 8 vols (Coimbra, 1552-1561), 7. 4; Richard Eden and Richard Willes, The history of travayle in the West and East Indies ... (London, 1577), IV. 7-8, ff. 384r-385r.

103 Strozzi Cicogna, Magiae omnifariae, Vel potius, Universae naturae theatrum, tr. Caspar Ens (Cologne, 1606), III.6, 355. In the fourth edition of the Anatomy, the compositor's erroneous attachment of the reference marker ( $\dagger$ ) for the note (referring to Cicogna) to a citation from Richard Argentine's De praestigïs et incantationibus daemonum et necromanticorum (1568) apparently confused Bamborough, who refers to Heinrich Kornmann's De miraculis mortuorum (2.45) as Burton's source for the story, and observes that the reference to Argentine is 'not from Cicogna' (IV, 228). The various difficulties in this part of the text can be cleared up by referring to Burton, Anatomy (1624), 43; Burton, Anatomy (1628), 46; Anatomy (1632), 48; Anatomy (1638), 49; and Anatomy (1651), 49.
} 
mentions the story, provide any useful details about the location of 'Rupes nova', beyond the fact that it was the name of the castle rather than a nearby settlement. ${ }^{104}$ But a likely answer is provided by the Cicogna's probable source, the Historia de gentibus septentrionalibus (1555) by the Swedish scholar and Archbishop Olaus Magnus (Olof Månsson). In chapter 19 of book 20, entitled 'De Piscibus Nigri fluminis ad Arcem novam in Finlandia', Olaus relates a story about black fish contained in a deep and dark river, fed by a lake and running by a castle built upon a circular mount, and reportedly situated in the outermost polar region of Finland. A marginal note explains that 'Arx nova' is also referred to as the home of 'St. Olav' ('Arx nova, corona terrae, vel domus S. Olai dicta'). ${ }^{105}$ This is almost certainly Olavinlinna (in Swedish, Olofsborg), built in the late fifteenth century on a small rocky island in the Kyrönsalmi strait, and located in what is now Savonlinna, actually in southeastern Finland. ${ }^{106}$ In chapter 20, Olaus explains the illustration prefacing his account of 'Arx nova' (Fig. 1), in which the black fish in the dark river are accompanied by a figure playing a lyre, which apparently prompts a man to fall head-first into the water. The image of the lyre-player is a portent that the governor or captain of the citadel will meet his fate by falling off the castle wall. ${ }^{107}$

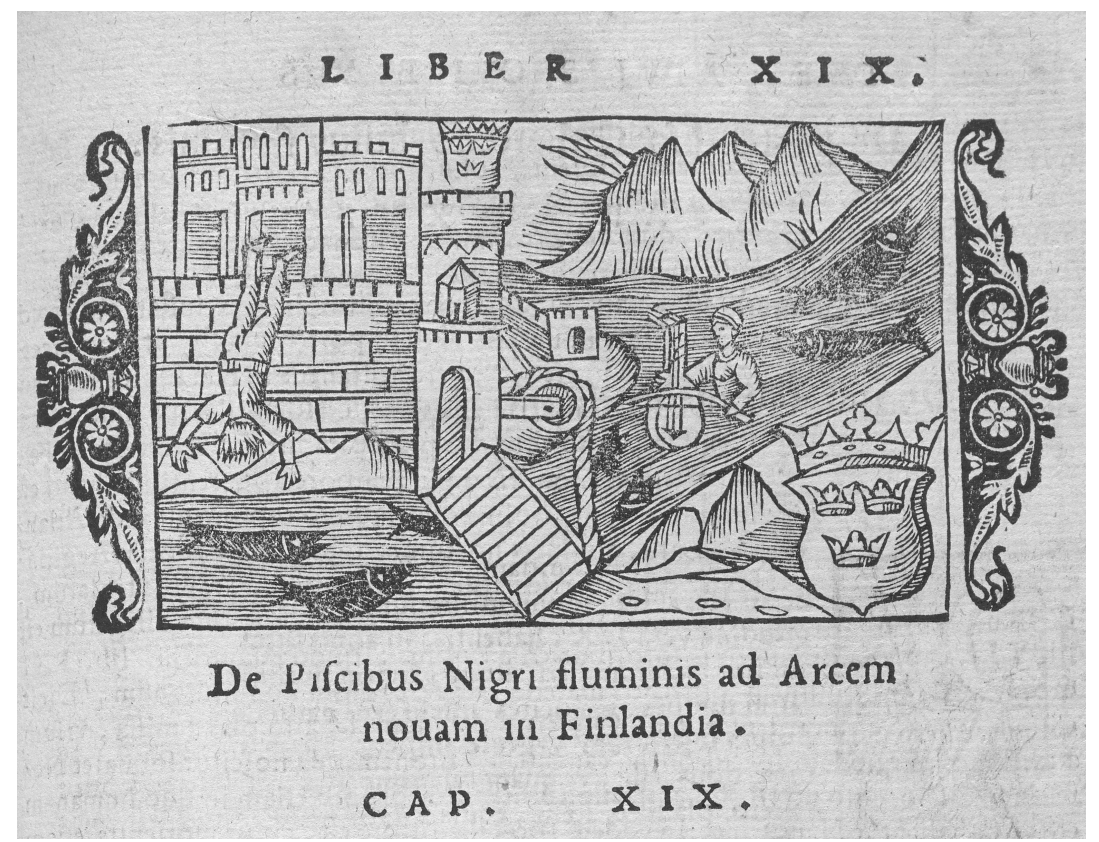

Fig. 1. Detail from Olaus Magnus, Historia de gentibus septentrionalibus (Rome, 1555), 715; the book number has been printed incorrectly. Reproduced by kind permission of the Syndics of Cambridge University Library (Sel.3.230).

\footnotetext{
104 See Heinrich Kornmann, De miraculis mortuorum (Frankfurt, 1610), 2.45, sig. D6v, which repeats Cicogna's account verbatim. 105 Olaus Magnus, Historia de gentibus septentrionalibus (Rome, 1555), XX.19, 715.

106 Olavinlinna was also the initial model for the castle of Kropow in King Ottokar's Sceptre (1939): see Stuart Tett, 'The RealLife Inspiration behind Tintin's Adventures', printed in Hergé, King Ottokar's Sceptre, tr. Leslie Lonsdale-Cooper and Michael Turner (London, 2013), 11.

107 Olaus Magnus, Historia, XX. 20, 716.
} 
Since Cicogna also mentions a deep black river, with black fish, and out of which the spirits presaging the death of the citadel governor (or of another soldier) are said to appear, this is surely the same castle he calls 'Rupes Nova'. ${ }^{108}$ The classical detail about Arion, the motive power of whose music is mentioned later in the Anatomy (2. 2. 6. 3; II, 114), probably comes from Burton's memory of the engraving in Olaus's book.

Another puzzling location is mentioned in the account of the strange marital customs reported amongst 'the inhabitants of Mambrium, in the Lucerne vally in Pedemont' (3. 3. 4. 2; III, 316-17). Burton gives his source as the Descriptio totius Italiae (1567) of Leandro Alberti, where as Bamborough notes (VI, 199), the town of 'Mambrinum' is said to be located at the head of the valley of the River Po, 'vel ut incolae vocant, livernae'. 109 The Italian version of Alberti's work, the Descrittione di tutta Italia (1550), which was the basis for the rather loose translation used in the Anatomy, is more helpful in locating 'Mambrinum', however. It confirms Burton's suggestion that the Latin 'Vallis Livernae' is the Valle di Lucerna (or Luserna), ${ }^{110}$ now known as the Val Pellice, an Alpine valley south-west of Turin. It also refers to 'Mambrino Castello' being known to the locals as 'Lucerna' after its own 'Lucerna Castello'. I suggest that 'Mambrinum' was the ancestor of what is now the town of Luserna San Giovanni, located in the Val Pellice, and host to the medieval Castello di Luserna. ${ }^{111}$

\section{Explanatory commentary.}

I come now to the more contentious territory of explanation. Although the Clarendon commentary offers generally sure and thorough guidance to the plethora of allusions, terminology, and doctrine found in the Anatomy, it contains some isolated but significant omissions which can be addressed here. I also propose some changes and supplements to the existing entries, for the purpose of further clarifying the sense and significance of the text. As we shall see, there are several places where Burton evidently presumes a readership that shares his education.

First we can deal with some literary allusions. One pair of these occurs in a passage on the tedium of servility, added in 1628: 'Socia ad pistrinam, Socia shall tarry at home and grinde mault all day long, Tristan thresh' (1. 2. 4. 6; I, 349). 'Socia' should indeed be 'Sosia' (V, 16), but whilst that name originates in Roman comedy, Burton's allusion is surely to La Celestina (1499) by Fernando de Rojas, to which (in the Latin translation of 1624 by Kaspar von Barth) he refers extensively elsewhere, and which features two servants called Sosia and Tristan; the phrase 'ad pistrinam', a Latin idiom which according to Thomas Elyot 'sygnifieth for peynefulle

\footnotetext{
108 The Swedish name for Savonlinna is 'Nyslott' (literally 'New Castle'). The substitution of terminology (rock/cliff for castle) remains puzzling; possibly it was prompted by the site of the citadel.

109 Leandro Alberti, Descriptio totius Italiae (Cologne, 1567), 709.

110 Leandro Alberti, Descrittione di tutta Italia (Bologna, 1550), f. 409r.

111 The discussion of Piedmont in Abraham Ortelius, Theatrum orbis terrarum (Antwerp, 1570), 34, reproduces parts of the text from Alberti; the accompanying map locates Luserna immediately west of Turin. See also the description in Annuae Litterae Societatis Jesu Anni. 1584 (Rome, 1586), 51.
} 
servyce', seems to be Burton's own import. ${ }^{112}$ Another pairing of literary characters, unidentified in the Clarendon commentary, is 'Lysander [and] Calista', who also first appeared in the third edition (3. 2. 5. 5; III, 269). They are the main protagonists in The Wandering Lovers by John Fletcher, which was performed at Whitehall in 1624, subsequently revised by Philip Massinger as 'Lasander \& Callista' (1634), and then published as 'The Lovers Progress' in the first Beaumont and Fletcher folio (1647). ${ }^{113}$ But for this to be Burton's source he would need to have attended or heard a report of the Whitehall production, and it is more likely that he drew the names from Fletcher's own probable source, the popular prose romance Histoire tragecomique de notre temps, sous les noms de Lysandre et de Caliste (1615) by Vital d'Audiguier, which had been translated into English in 1617 by William Duncombe. Slightly more puzzling are the references to 'Sostratu's bitch, or Parmeno's sow' (3. 2. 3; III, 167). Bamborough suggests that 'Sostratus' is meant, and writes that '[b]oth these names occur in Terence's Adelphoe, but are probably used here generically' (VI, 110). Actually the Adelphoe includes an Athenian widow named Sostrata, and other persons called Sostratus, such as the character in Menander's Dyskolos, are unpromising candidates. ${ }^{114}$ However, if the reference to Parmeno is taken as a reference to the Adelphoe, it is more plausible to suppose that Burton intended 'Sostrata', but the compositor misread or mis-set the final letter, and the error remained unnoticed. ${ }^{115}$ In any case, there is here an additional layer of allusiveness at work, referring to the ancient proverbial saying about popular delusion, 'Nothing to Parmeno's sow'. This reportedly originated in the imitation of a pig's voice given by a certain Parmeno, which gained more applause than that of a real pig, and given its inclusion in the Adagia of Erasmus, Burton's familiarity with it may be assumed. ${ }^{116}$

Burton does not always deign to explain the more abstruse technical content of the Anatomy, some of which benefits from further attention. In a discussion of the diverse psychological symptoms of melancholy that has been quoted in recent scholarship, ${ }^{117}$ he comments on the condition:

To some it is in disposition, to another in habit; and as they write of heat and cold, we may say of this humour, one is melancholicus ad octo, a second two degrees lesse, a third halfe way. 'Tis super particular, sesquialtera, sesquitertia,

\footnotetext{
112 Thomas Elyot, Bibliotheca Eliotae: Eliots librarie, $2^{\text {nd }}$ edn (London, 1542), sig. Gc.iiiiv. The phrase is later used in this sense by Thomas Willis in his prefatory letter to the De fermentatione (Opera Medica \& Physica [Lyon, 1676], at sig. ii.4r).

113 See Fredson Bowers (ed.), The Dramatic Works in the Beaumont and Fletcher Canon, 10 vols (Cambridge, 1996), 10. 427.

114 Burton's access to Menander came via fragments available in other writers and the moral sententiae attributed to Menander, later collected in Hugo Grotius and Jean Leclerc (eds), Menandri et Philemonis Reliquiae, Quotquot reperiri potuerunt (Amsterdam, 1709), and Tiberius Hemsterhuis (ed.), Luciani Samosatensis Colloquia selecta, \& Timon. Cebetis Thebani Tabula. Menandri Sententiae Morales (Amsterdam, 1708). The fragments quoted in the seventeenth century include references to Parmeno but not to Sostratus: Alfred Koerte (ed.), Menandri quae supersunt: pars altera: Reliquiae apud veteres scriptores servatae (Leipzig, 1959).

115 It is also possible, if unlikely, that Burton meant to refer to the character Sostrata in Machiavelli’s Mandragola.

${ }_{116}$ Erasmus, Adagia 10. 1. 1. 10, in Desiderius Erasmus, Adages I $i$ to I v 100, ed. R. A. B. Mynors and tr. Margaret Mann Phillips (Toronto, Buffalo and London, 1982), 59-60.

117 Angus Gowland, The Worlds of Renaissance Melancholy: Robert Burton in Context (Cambridge, 2006), 111; Christopher Tilmouth, 'Sceptical Perspectives on Melancholy: Burton, Swift, Pope, Sterne', RES, 68 (2017), 924-44, at 934.
} 
and superbipartiens tertias, quintas, Melancholiae, \&c. all those Geometricall proportions are too little to expresse it (1.3. 1. 4; I, 404-5).

The Clarendon commentary translates 'melancholicus ad octo' as 'Melancholy to the eighth degree' and 'sesquialtera ... Melancholiae' as 'Melancholy in proportions of three to two, four to three, five to three, and seven to five', and glosses the term 'super particular' with the OED entry (s. v. 'superparticular'), as a term '[a]pplied to a ratio in which the antecedent contains the consequent once with one aliquot part over ... i.e. $(n+1): n$ ' $(\mathrm{V}, 51)$. More ought to be said. In the first sentence, Burton consciously imports one of the common topics of contemporary Aristotelian physics, concerned with the definition of the elements, in which numerical degrees of heat, coldness, dryness and moisture were routinely considered and disputed. ${ }^{118}$ However, although learned physicians addressed the quantitative as well as quantitative dimensions of bodily temperaments and drugs, ${ }^{119}$ I know of no precedent in Burton's medical sources for the quantitative numerical description of the melancholic 'humour', whether one takes that to refer to black bile, or (as the surrounding discussion suggests) the mental condition or mood. ${ }^{120}$

In the second sentence, Burton borrows the proportional terminology of ancient mathematics, which at the time included two of the disciplines he would have studied at Oxford for his BA and MA, music and geometry. ${ }^{121}$ His more learned readers would have recognized the technical names of the various ratios, which are expounded in the Liber musices (1492) by Florentius de Faxolis as follows: ' $[\mathrm{t}]$ he 'superparticular [superparticulare] is when the greater number contains the smaller', with an exact divisor or factor of the smaller number left over, as in $3: 2,6: 4$, etc.; the 'sesquialter [sesqualtera] is when the greater number contains the smaller once with half the smaller', as in $3: 2,6: 4,12: 8,15: 10$, etc.; the 'sesquitertia' [sesquitertia] is 'when the greater number contains the smaller once and the third part of the smaller number', as in $4: 3,8: 6,12: 9,16: 12$, etc. ${ }^{122}$ The triple superbipartient (superbipartiens tertias) occurs when the greater number contains the smaller plus two parts, the sum of which is not an exact divisor of the smaller, and is also two-thirds of the smaller, as in $5: 3$; the 'quintuple superbipartient' is when the greater number contains the smaller plus two parts, the sum of which is not an exact divisor of the smaller, and is also two-fifths of the smaller, as in $7: 5 .{ }^{123}$

\footnotetext{
118 See, for example, Pedro Hurtado de Mendoza, Universa philosophia (Lyon, 1624), V, §§38-44, 469-70.

${ }^{119}$ Edith Sylla, 'Medieval Quantifications of Qualities: The "Merton School”', Archive for History of Exact Sciences, 8 (1971), 9-39, at 16-24. See, for example, Arnau de Vilanova, De graduationibus medicinarum per artem compositarum, in his Opera (Lyon, 1532), ff. 223r-233v.

120 See, however, Burton's comments about the degree of pathological affliction at 1. 1. 1. 4; I, 132 and 1. 1. 1. 5; I, 139. Related ideas are expressed at 1. 3. 2. 4; I, 416, and the qualitative degrees of foodstuffs and remedies are mentioned at 1.2. 2. 1; I, 212; 2. 4. 1. 3; II, 217; 2. 4. 2. 1; II, 227-28.

121 See Mordecai Feingold, 'The Mathematical Sciences and New Philosophies', and Penelope M. Gouk, 'Music', both in Nicholas Tyacke (ed.), The History of the University of Oxford, vol. 4: Seventeenth-Century Oxford (Oxford, 1997), 359-448, at 366-89, and $621-640$, at 623 .

122 Florentius de Faxolis, Book on Music, ed. and tr. Bonnie J. Blackburn and Leofranc Holford-Strevens (Cambridge, MA, 2010), III.17, 198-201.

${ }^{123}$ Florentius, Book on Music, 204-5, 210, 295. For a more contemporaneous but less accessible English exposition, see Euclid, The elements of geometrie, tr. Henry Billingsey (London, 1570), ff. 127v-128r.
} 
Again, whilst the theory of proportion was used by learned physicians for the measurement of therapeutic drugs and the determination of health, complexion, and humours, ${ }^{124}$ Burton here consciously applies severely technical terminology not found in his medical sources, conveying the idea that the melancholic condition occurs in a great variety of proportions, the fine and complex differences between which are practically impossible to grade, even with the exact language of geometry.

A second place requiring more explication occurs in the discussion of the symptoms of 'excessive' religious melancholy, where in a passage added to the third edition Burton comments on the Roman veneration of 'Kings, Emperours' and 'valiant men':

For so they were Semi-dii, demie-gods, some medii inter Deos $\&$ homines, as Max. Tyrius, the Platonist, ser. 26. E 27. maintaines and justifies in many words. When a good man dies his body is buried, but his soule ex homine daemon evadit, becomes forthwith a Demi-god, nothing disparaged with malignity of ayre, or variety of formes, rejoyceth, exalts and sees that perfect beauty with his eyes ... (3. 4. 1. 3; III, 371).

The attached marginal note gives some of the Latin text for Burton's quotation, and refers to the translation of Maximus's Sermones sive disputationes XLI by Cosmo de' Pazzi, which Burton owned in the Stephanus edition printed in 1557 at Geneva. ${ }^{125}$ Bamborough observes that in Sermo 27 (9 in modern editions) Maximus states that the nature of daemons lies between man and God, and then locates the longer quote later in the same disputation (VI, 242). ${ }^{126}$ However, he ignores the perplexing phrase which Burton has left in Pazzi's Latin: 'ex homine daemon evadit'. To understand this, we need to look more closely at Sermo 27, which draws on a Greek tradition of thinking about daimones as the formerly embodied souls of men, and claims that 'a daemon is nothing other than a soul that has shed its body'. ${ }^{127}$ How so? When body and soul are conjoined, the former is held together by the latter, but just as a ship can be held steady in a storm by a series of ropes tied to a firm rock, so

... when friction weakens the nerves or spirits, which are like the ropes somehow tethering the body to the rock of the soul, the body too succumbs to corruption, and is dragged into the deep; but the soul, swimming by its own powers, holds itself together and remains firm. It thereafter takes the

\footnotetext{
${ }^{124}$ Maclean, Logic, Signs and Nature, 176-7.

125 Maximus Tyrius, Sermones sive disputationes XLI, tr. Cosmo de’ Pazzi (Geneva, 1557); Kiessling, Library of Robert Burton, no. 1029. The passage quoted by Burton is at p. 209. The copy held at Christ Church (Wn.7.9), of which there is no evidence of Burton's ownership, has no annotations. 126 Maximus Tyrius, Sermones, XXVII, 205, 209-10.

127 Maximus Tyrius, Sermones, XXVII, 207-8: 'Quum nihil aliud sit daemon quam nudus animus, corpore deposito?'; cf. Apuleius, De deo Socratis XV-XVI, in Apologia; Florida; De deo Socratis, ed. and tr. Christopher P. Jones (Cambridge, MA, 2017), 374-79; Plutarch, De genio Socratis 593D-594A, in Moralia, tr. Philip H. De Lacy and Benedict Einarson, vol. 7 (London, 1959), 480-85. For discussion of this conception of daimon, see John M. Dillon, The Middle Platonists (London, 1977), 216-24, and Andrei Timotin, La démonologie platonicienne: Histoire de la notion de 'daimōn' de Platon aux derniers néoplatoniciens (Leiden and Boston, 2012), 31-4, 52-84, 201-8.
} 
name of 'daemon', and becomes a creature of the air, and from then on is its child, having been transferred there away from the earth ... ${ }^{128}$

In death therefore, when the soul sheds the body and leaves it to its earthly corruption, 'the daemon comes out of the man [ex homine daemon evadit], and with clear eyes gazes upon its proper sights'. ${ }^{129}$ Whereas the phrase 'ex homine daemon evadit' in Maximus refers to the changing of the soul into a daemon, Burton's paraphrase ('becomes forthwith a Demigod') is a tendentious gloss supporting his critique of ancient superstition. However, his account does accurately convey the idea that the souls of the virtuous departed may become, as Maximus writes in Sermo 26, less powerful than full divinities but far more powerful than men. ${ }^{130}$

The Anatomy's attack on superstition presents another technical difficulty for readers without Burton's education. Amongst the ridiculous 'rabble of idle controversies \& questions' produced by Roman Catholic theologians and clergy, Burton lists ' $[\mathrm{w}]$ hether it bee as possible for God to be a Humble Bee, or a Gourd as a man?', and '[w] hether he can produce respect without a foundation or terme, make a Whore a Virgin?' (3. 4. 1. 3; III, 386). ${ }^{131}$ The arcane question of the divine capability to 'produce respect without a foundation or terme' is paraphrased by Bamborough as ' $[\mathrm{w}]$ hether He can create the appearance of something without the substance or any limit' (VI, 254); unfortunately, this quite mistakes the terminology, which belongs to scholastic logic and metaphysics. The word 'respect' is being used in the logical sense, corresponding to the Latin respectus, of a 'relation', not as a synonym for an astrological 'aspect'. ${ }^{132}$ This provides the context for Burton's use of the words 'foundation' and 'terme', which correspond in the Latin terminology to fundamentum and terminus. We are here encountering the three principal elements of the so-called 'predicamental accident' of relation, which following the Disputationes metaphysicae (1597) of Francisco Suarez are: 1. the being (or 'subject') that is related to another; 2. the being to which the 'subject' is related (the terminus or 'term'); and 3. that which is in both 'subject' and 'term' and provides the grounds for the

\footnotetext{
${ }^{128}$ Maximus Tyrius, Sermones, XXVII, 208-9: 'At ubi nervos ac spiritus, veluti retinacula quaedam, per quae interim corpus ab animi quodammodo mole sustinetur, consumpserit attritio: corpus quidem corruptioni succumbit, \& in profundum rapitur, animus vero propriis viribus enatans, seipsum continet, firmusque consistit. Is deinceps nuncupationem daemonis accipit, fitque aeris, protinus alumnus, ex terra in ipsum ... translatus'.

129 Maximus Tyrius, Sermones, XXVII, 209: 'Nam postquam animus deposito corpore, decedens, hinc se in illum locum statuerit, corpusque terrae corrumpendum reliquerit, ipso momento legeque, ex homine daemon evadit, purisque oculis propria spectacula intuetur'. The later translation by Daniel Heinsius has 'Cum ergo ex his locis eo se contulerit anima, corpusque suum exuerit, ac terrae corrumpendum reliquerit, eodem tempore ac lege daemon fit ex homine, purisque oculis spectacule intuetur sua' (Dissertationes philosophicae, tr. and ed. Daniel Heinsius [Leiden, 1614], 278). The pertinent Greek phrase

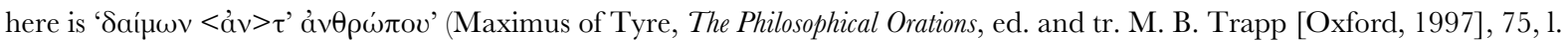
141).

130 Maximus Tyrius, Sermones, XXVI, 202.

131 The first and second editions have 'produce a respect': Burton, Anatomy (1621), 755; Anatomy (1624), 524.

132 See, for example, Pierre Du Moulin, The elements of logick, tr. Nathanael De-Lawne (London, 1624), 6, 8, where 'Relation or Respect' is identified as one of the ten categories or predicaments; see also Hurtado de Mendoza, Universa philosophia, XV.1, 897: 'Relatio solet appellari respectus'. The OED entry for 'respect' correctly cites the passage in question from the Anatomy as an illustration of sense II. 5. a: 'The fact of standing in a relationship with another person or thing; relationship, reference': 'respect, n. (and int.)', OED Online (pubd online March 2000) <www.oed.com/view/Entry/163779> accessed 17 April 2018).
} 
relation (the fundamentum or 'foundation'). When the 'subject', 'term', and 'foundation' are all real, it is described as a 'real relation' (relatio realis) which is independent of the mind. When either the 'term' or 'foundation' are not real, that is, produced by the mind, it is called a 'relation of reason' (relatio rationis). ${ }^{133}$

With this logical and metaphysical vocabulary in mind, we can now see that the question to which the Anatomy refers arises from scholastic theological debates about divine omnipotence and God's relation to the world: can God produce a relation ('respect') without real grounds for that relation, or indeed without a real object to which He could be related? The most important locus for this kind of discussion, which became the subject of controversy between Ockhamists and Scotists, and to which Suarez, Hurtado de Mendoza, and other late scholastics turned, was the Summa theologiae of Thomas Aquinas (I 13. 7, 28. 1). Here it is argued that although the relation between creation and God is real, the relation between God and creation is one of reason; this is because God and creation are of an entirely different order, leaving that relation without a real 'foundation'. ${ }^{134}$ In line with the denunciation of theological curiosity elsewhere in the Anatomy, Burton is of course ridiculing this kind of dispute as absurdly futile, accentuating the satire by associating the question of whether God can 'make a Whore a Virgin'. But we can also note the divisive effect of his casual employment of rarefied technical terminology: by offering no guidance, he separates readers who grasp the logical and theological meaning - including those of his contemporaries who have taken the university arts course, and who may, like Burton, have studied at least for the BD - from those who do not, and whose likely confusion one might consider, given his argument at this point, to be quite appropriate.

\section{$V$. The text and its readers.}

Burton knew, as he put it in his first edition, that he would have to endure 'the common fate of all writers', and that his work would be received in different ways - 'laudamur ab his culpamur ab illis', praised by some, condemned by others. As he explained, the diversity of the Anatomy's reception would be a product not just of its multifarious content, but also of the varying knowledge and ability of its readership, since, according to the famous maxim of Terentianus, 'Pro captu lectoris habent sua fata libelli' ('Books have their fates, depending on the capacity of the reader'). ${ }^{135}$ For its more educated readers, as we have seen, the Anatomy presented a wealth of

\footnotetext{
133 Francisco Suarez, Metaphysicarum disputationum ... tomi duo, vol. 2 (Mainz, 1605), XLVII.6, 514-16. On this area of scholastic logic see Massimo Mugnai, 'Leibniz's Ontology of Relations: A Last Word?', in Daniel Garber and Donald Rutherford (eds), Oxford Studies in Early Modern Philosophy, Vol. 6 (Oxford, 2012), 171-208, at 173-82.

134 Thomas Aquinas, Summa theologiae, ed. Pietro Caramello, vol. 1 (Turin, 1948), 70, 152. For subsequent discussion, see for example Hurtado de Mendoza, Universa philosophia, XV, 897-923, and Richard Baxter, Catholick theologie plain, pure, peaceable ... (London, 1675), I.4, 8.

135 Burton, Anatomy (1621), 10. The quotation from Terentianus was retained in later editions (DJR; I, 13), but in 1624 the observation about the 'common fate' of authors was relocated to a later passage, where censure and calumny became 'common doom' (I, 15-16).
} 
material to be located and interpreted within their humanistic literary and intellectual milieux. But it did also make substantial efforts to accommodate those whose knowledge was less extensive, providing translations or paraphrases of many of the Latin quotations, as well as explanations of most of its more recondite technical vocabulary and concepts. ${ }^{136}$ In this respect, as Burton wrote in 'Democritus Junior ad librum suum', 'Gratus erit quicunque venit, gratissimus hospes' ('Whoever comes will be welcome, a most welcome guest') (I, lxviii).

This view of the intended readership of the Anatomy has wider implications for our understanding of the work. Much recent scholarship has focused on the role of reading in the text, and has usefully focused our attention on Burton's overarchingly therapeutic concern to provide his audience with a beneficial and pleasurable experience. ${ }^{137}$ An important corollary of this concern is the author's awareness of the variety of his readership, whether melancholic or not; or, to put it another way, Burton is able to apply himself 'for the common good of all' (DJR; I, 8) by imagining a universalized reader. ${ }^{138}$ Whilst this hypothetical concept serves to illustrate some of Burton's purposes - and in places he does address his reader 'whosoever thou art' (1. 2. 5. 5; I: 380) - it also obscures significant features of the work that are aimed at particular kinds of reader with differing levels of education. For as the contents of the monumental Clarendon commentary have suggested, and as this essay has tried to show, the Anatomy punctuates its didactic exposition of subject matter more or less continuously with literary and intellectual referentiality, much of which would have been lost on those without humanistic training of the fairly thorough kind given by the university arts course, and some of which would have been accessible only to those who had, like the author, been immersed in reading and scholarship for many years.

Adopting this perspective also prompts us to revisit Burton's somewhat perplexing claim that he originally intended to write his book in Latin, but that he was forced to 'prostitute' his Muse in the vernacular by 'our mercenary Stationers' (DJR; I, 16). Bamborough detects a possible 'element of disingenuousness' here, suggesting that if Burton had really written purely in Latin he would have thereby sacrificed the 'therapeutic effect' of his book on its 'educated' English audience, most of whom - presumably Bamborough means those who had attended grammar school - could anyway read the Latin quotations 'with reasonable ease' (I, xxxv). This may be true, but bare Latinity does not suffice for the full appreciation of Burton's handling of the materials in his cento. Actually, the claim to be writing 'for the common good of all' is not the same as the claim to be writing to everyone, and for someone like Burton - who also uses Horace (Epistulae 1. 19. 37) to say of himself that 'Non ego ventosae venor suffragia plebis' ('I don't hunt for the votes of the fickle commoners') - it probably reflects the learned view that

\footnotetext{
${ }^{136}$ On this aspect of the Anatomy see Gowland, Worlds of Renaissance Melancholy, 96; Mary Ann Lund, Melancholy, Medicine and Religion in Early Modern England: Reading 'The Anatomy of Melancholy' (Cambridge, 2010), 78-92.

137 Stephanie Shirilan, Robert Burton and the Transformative Powers of Melancholy (London \& New York, 2016); Lund, Melancholy, Medicine and Religion; Vicari, The View from Minerva's Tower.

138 See, for example, Lund, Melancholy, Medicine and Religion, 24-45, or, less successfully, John Miller, 'Plotting a Cure: The Reader in Robert Burton's Anatomy of Melancholy', Prose Studies, 20 (1997), 42-71. For an acute discussion, see Murphy, 'A Disagreeing Likeness', esp. pp. 226, 235.
} 
the best way of serving the common good is by attending to the minds of the well-educated, particularly those who attend universities. ${ }^{139}$ Of course, the Anatomy would have been very different without its English translations and paraphrases, and its author had the consolation that he could still address himself to an audience comfortable in the fluent exchanges between Latin and vernacular language that had become prominent in late humanist culture. But there is good reason to suppose that Burton was being sincere in his complaint about English publishers. He had been agitated about the decline of Anglo-Latin writing at least since 1612, when in his preface to Rider's Dictionarie he relayed the grievance of the Oxford geographer Richard Vernam that publishers were sacrificing the advancement of letters to their own pursuit of profit by neglecting the continental market. ${ }^{140}$ There are several places in the main treatise, when Burton has clearly decided that his subject matter is inappropriate to a nonscholarly audience, where the ability and inclination to read more than just the occasional Latin quotation is required for even the most basic understanding of the text. The same holds for his copious notes, which are mostly composed in Latin, and regularly supplement the main text in significant ways. ${ }^{141}$

All books give different things to their different readers, although the highly variegated text of the Anatomy is perhaps unusual in the way its offerings have been differentially modulated for an audience with varying interests, capacities, and motivations. Perhaps, however, we should not lose sight of the transformative potential of reading, which suggests another possibility: that engaging with the book might turn us each into a different kind of reader - or, as Burton says, that his writing, 'like guilded pilles ... so composed as well to tempt the appetite, and deceave the pallat', may 'recreate' and 'rectifie' our minds (3. 1. 1. 1.; III, 5). I cannot be alone in finding this to be true of my own experience of the Anatomy, which over time has passed erratically through phases of curiosity, amusement, bewilderment, frustration, wonder, and reverence, but which, as the pages have continued to yield more, has also drawn me steadily closer to the text in search of the author, his books, and the world of literature and learning that he inhabited. In that enterprise, the challenges of the Anatomy, of trying to track down unknown sources and reconstruct obscure meanings, have also become some of its best pleasures. If their discovery does not necessarily lead us to run 'naked forth of the bath' like

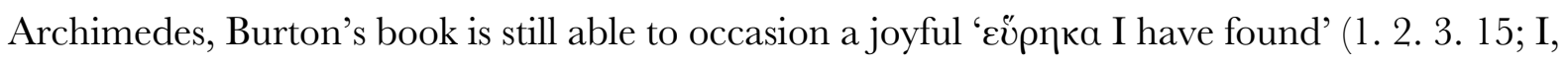
305-6).

\footnotetext{
139 Richard Serjeantson, 'Hobbes, the Universities, and the History of Philosophy', in Conal Condren, Stephen Gaukroger, and Ian Hunter (eds), The Philosopher in Early Modern Europe: The Nature of a Contested Identity (Cambridge, 2006), 118-22; cf. Lund, Melancholy, Medicine and Religion, 34-5.

${ }^{140}$ John Rider, Riders Dictionarie Corrected, and with the addition of above give hundred words enriched (Oxford, 1612), sig. ๆ4r; Vernam's remarks are quoted from Nicholas Carr, De scriptorum britannicorum paucitate oratio (London, 1576), fol. 8v, which is also subsequently incorporated within Burton's complaint in the Anatomy (I, 16).

${ }^{141}$ By my calculation, the book contains 5,250 Latin quotations or passages that are neither translated in the text nor closely paraphrased to preserve the majority of the sense; for some lengthy untranslated passages, see 1. 2. 3. 15; I, 324-27, 3. 1. 1. 1; III, 6-7, 3. 2. 1. 2; III, 49-51, and 3. 2. 5. 1; III, 206-7. Burton's use of Latin is discussed in Lund, Melancholy, Medicine and Religion, 36-7; the view expressed in Gowland, Worlds of Renaissance Melancholy, 30-1, is now being partially revised.
} 